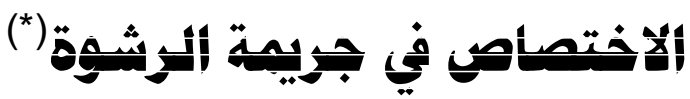

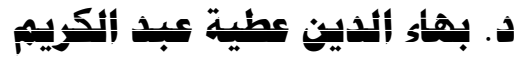

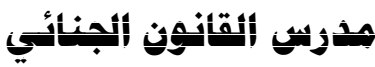

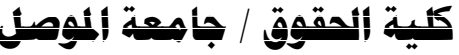

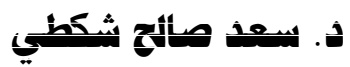

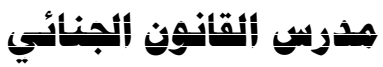

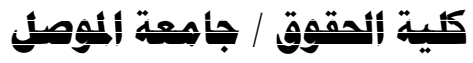

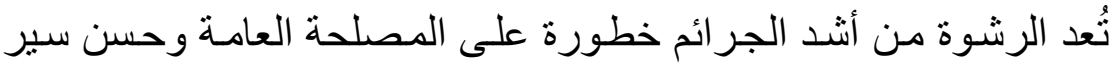

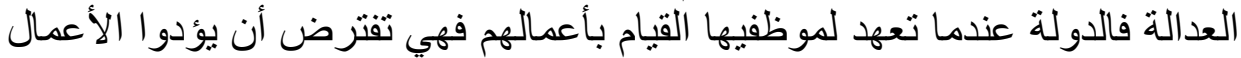

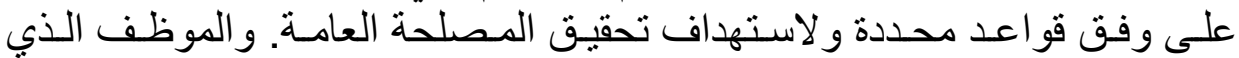

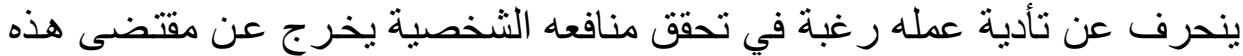

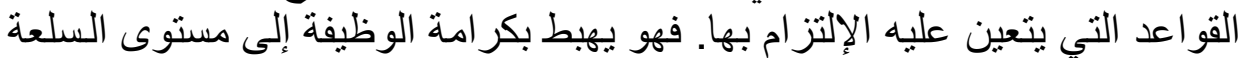

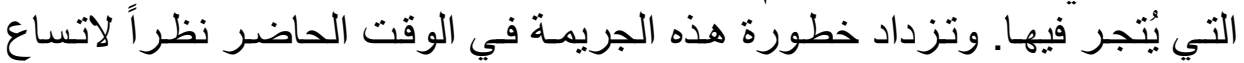

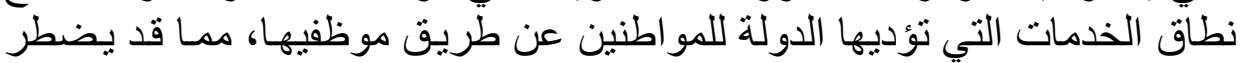

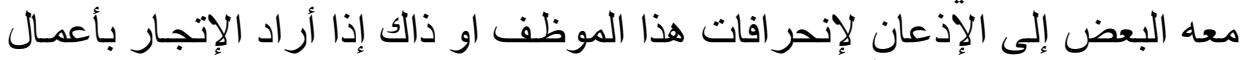

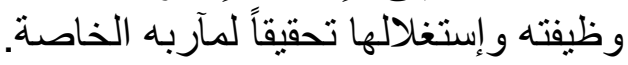

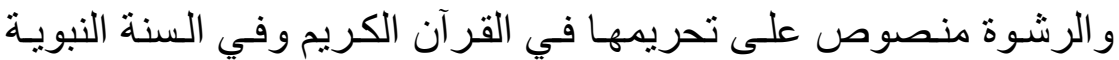

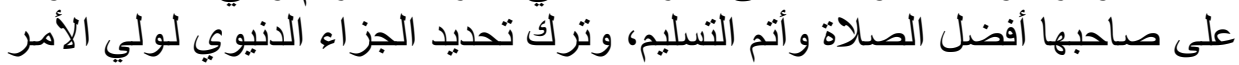

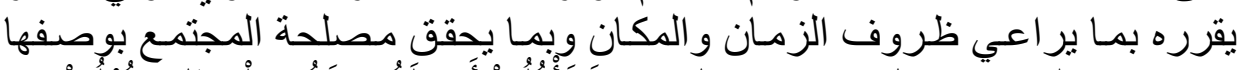

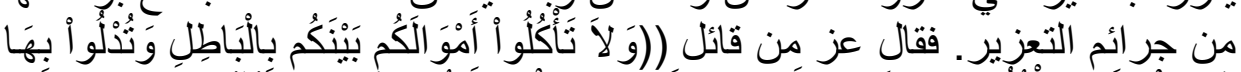

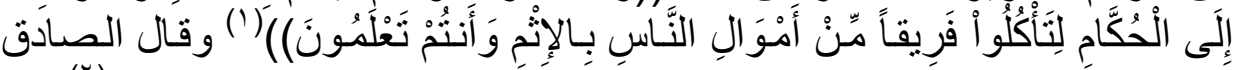

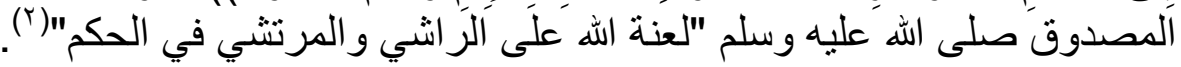

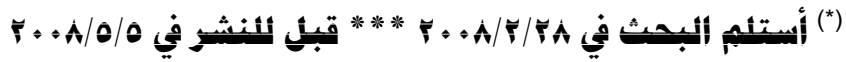

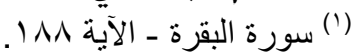

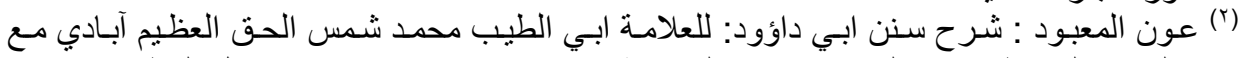

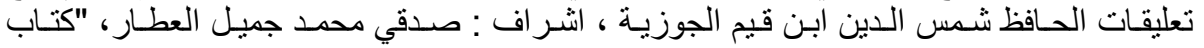

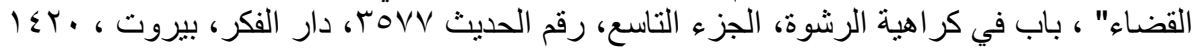

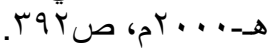




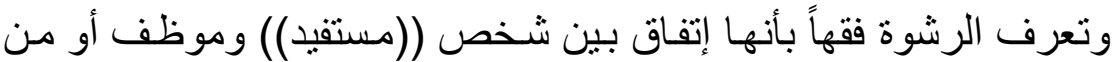

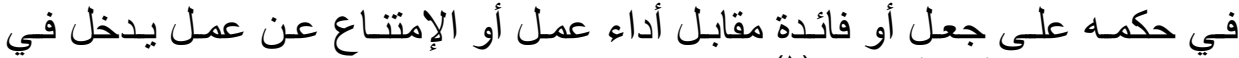

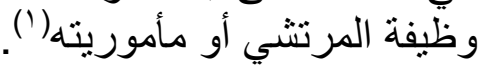

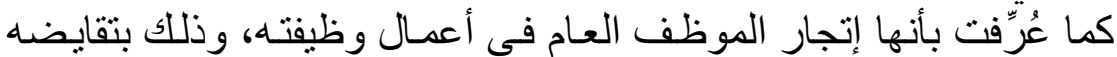

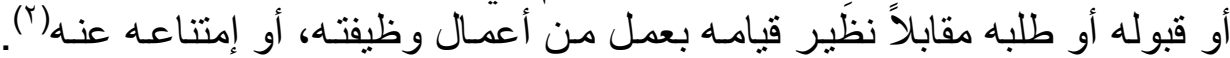
نخلص من التعريفات المتقدمة:

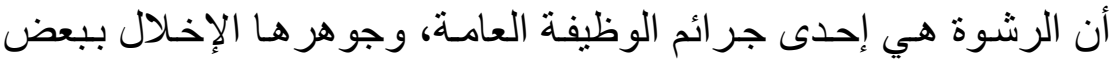

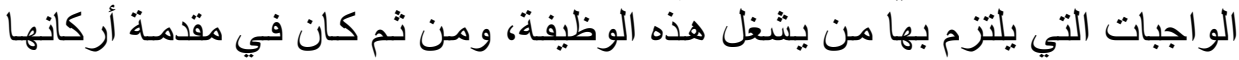

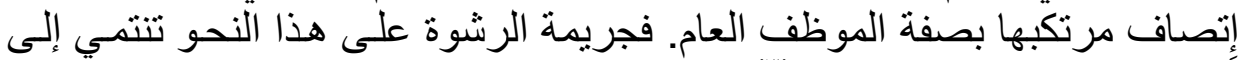

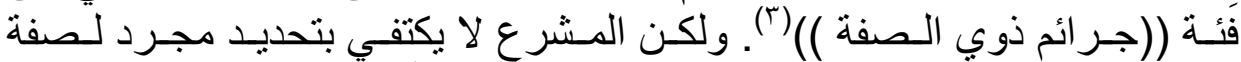

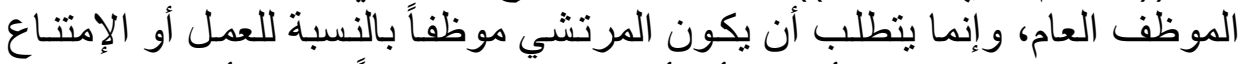

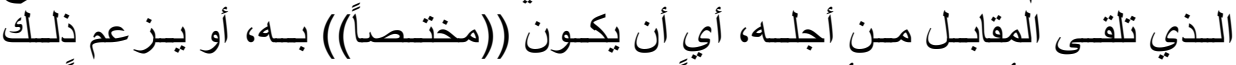

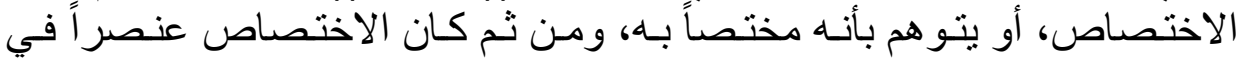
صفة الموظف العام كما تتطلبها جريمة الرشأه التهوة.

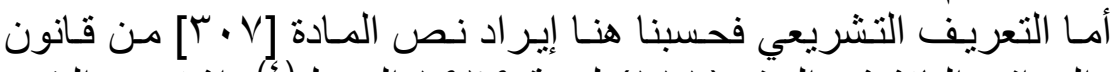

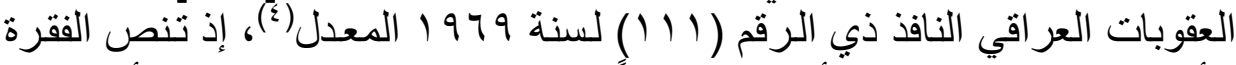

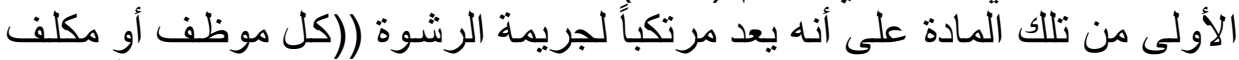

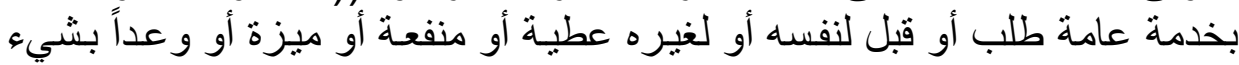

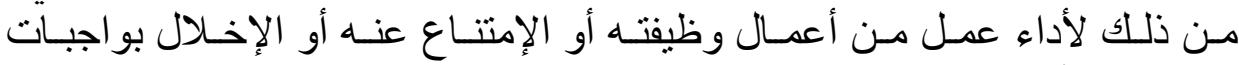

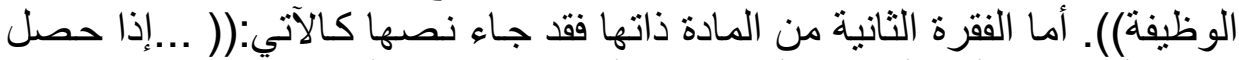

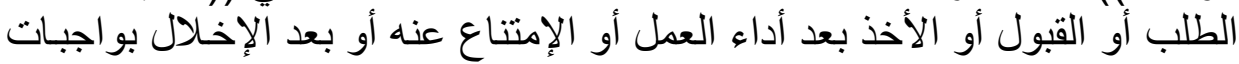
الوظيفة بقصد المكافأة على ما وقع من ذللك)).

(") ينظر : د.محمد مصطفى القللي، في المسؤولية الجنائية، مطبعة جامعة فؤاد الأول، القاهرة، عد9 19،

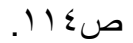
(ء) ينظر: د. محمود نجيب حسني، شرح قانون العقوبات، القسم الخاص، دار النهضة العربية، القاهرة،

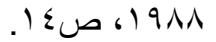

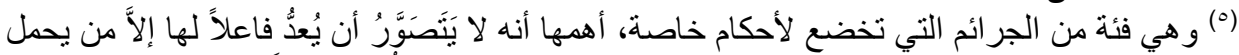

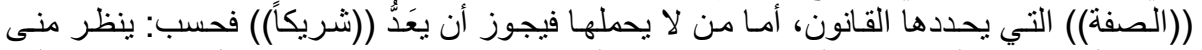

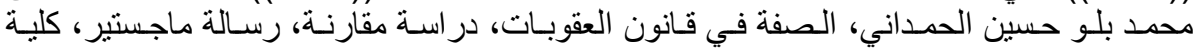

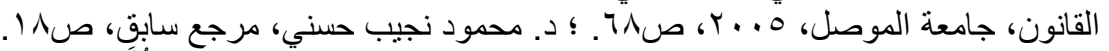

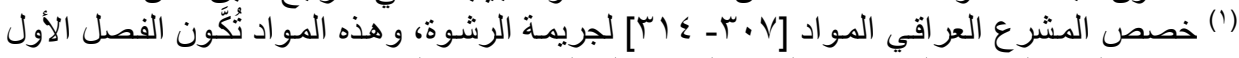
ضمن الباب السادس الذي عنون له بـ [الجر ائم المخلة بواجئ الجبات الوظيفة] 


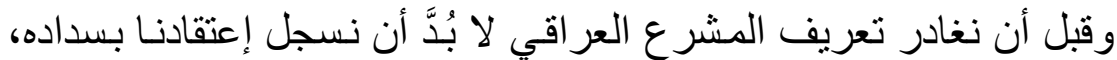

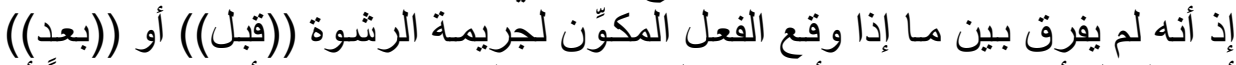

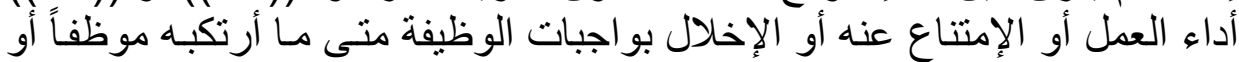

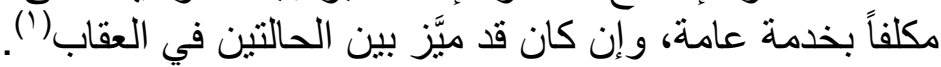

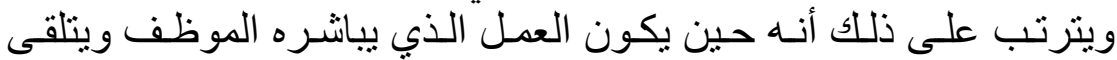

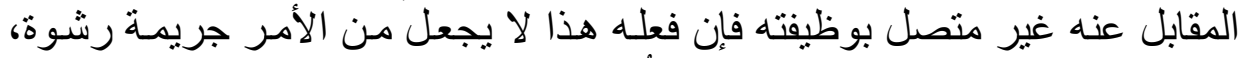

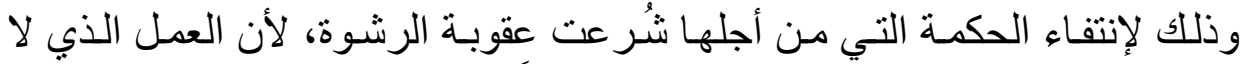

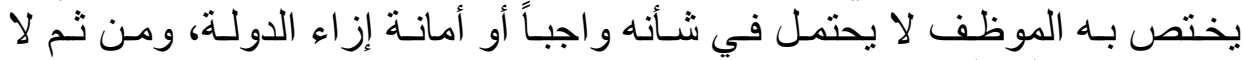

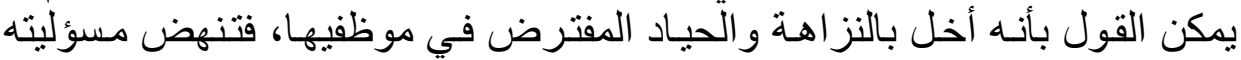

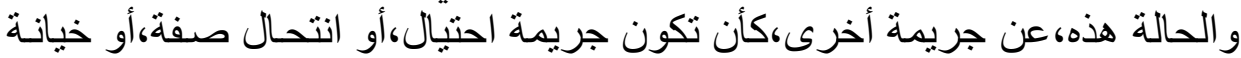

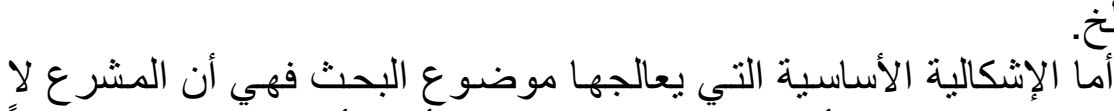

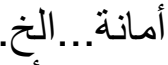

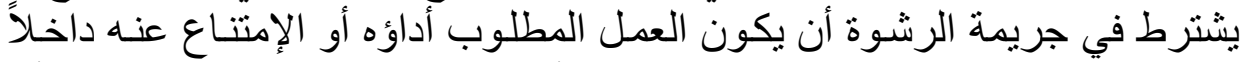

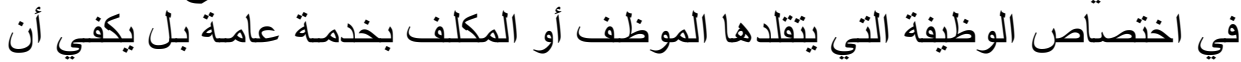

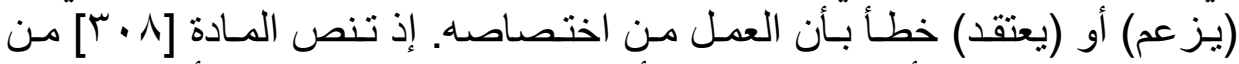

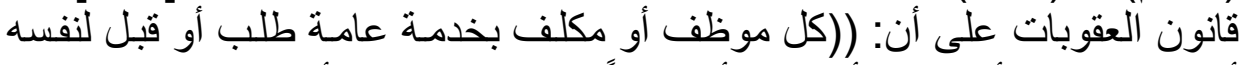

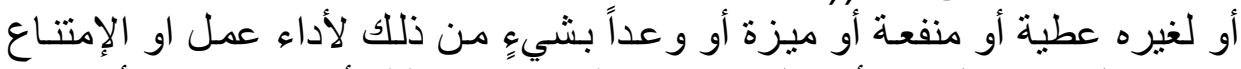

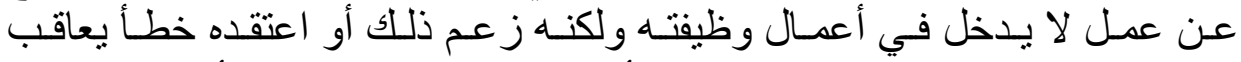

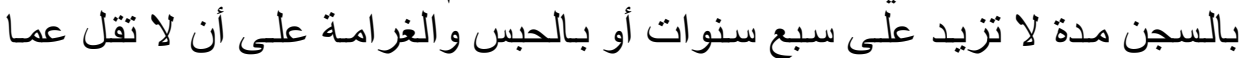

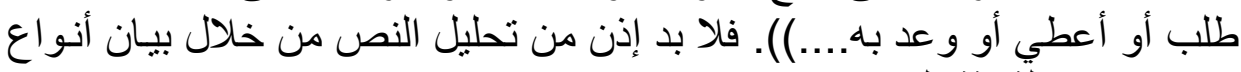

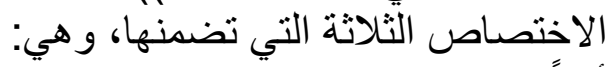

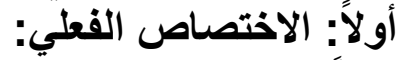

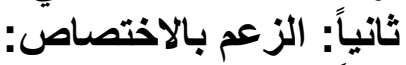
ثالثاً: الإعتقاد الزعاطئ بالإختص: بإصاص:

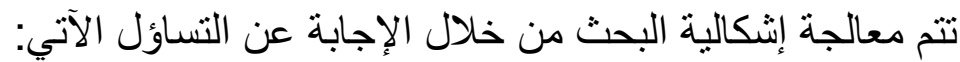

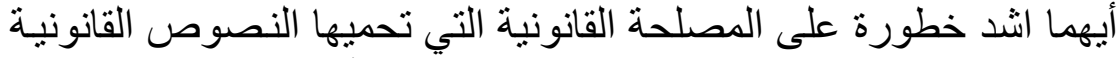
المتعلقة بجريمة الرشوة؟ هل صاحب الاختصاص الفعلي؟ أم هو الذي يزعم ذلك الك الك

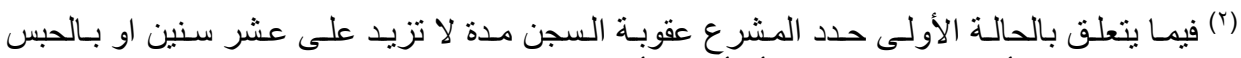

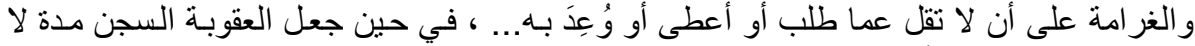

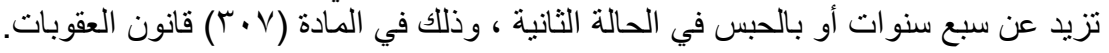


$19 r$

الاختصاص في جريمة الرشوة

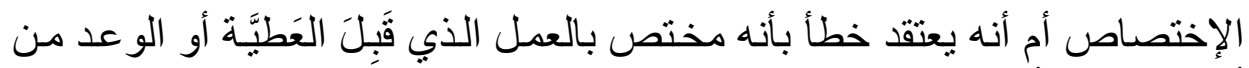

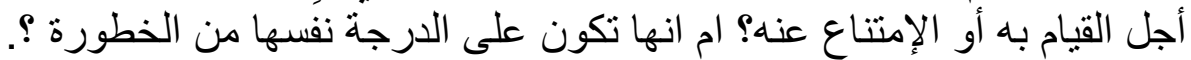

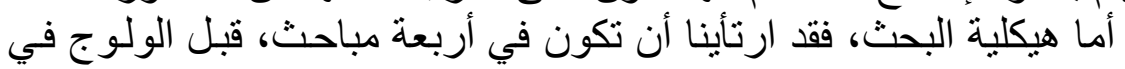

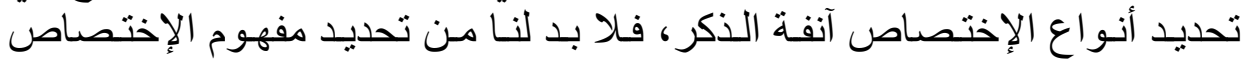

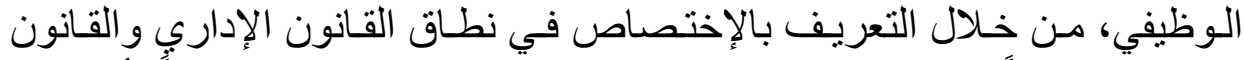

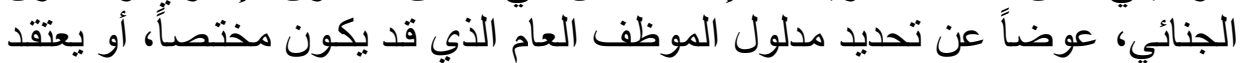

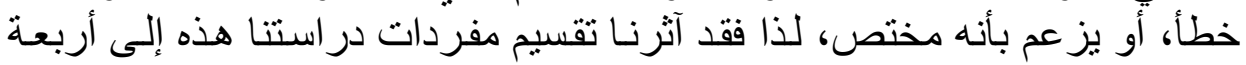

مباحث وكالآتي:-

المبحث الأول: مفهوم الاختي: الاختصاص الوظيفي.

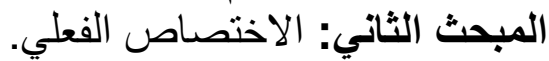

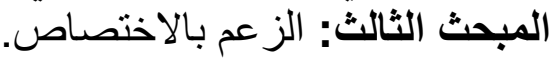

المبحث الرابع: الاعتقاد الخاطئ بالاختصاص.

Rafidain Of Law Journal, Vol. (10), No. (37), Year (2008) 


\section{أبجبث الأهول}

\section{مفهريم الإختصأص ألمظظيفي}

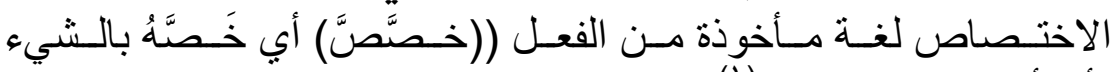

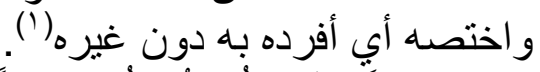

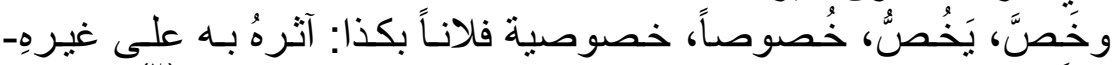

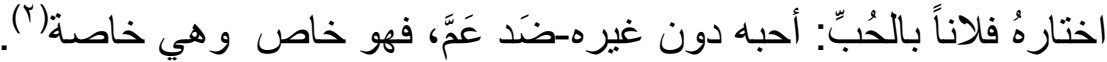

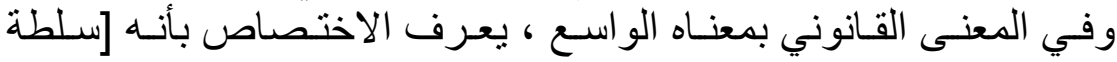

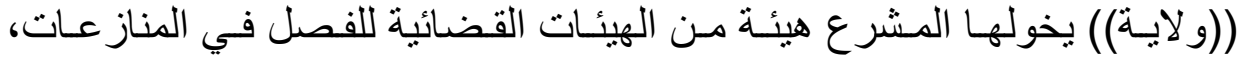

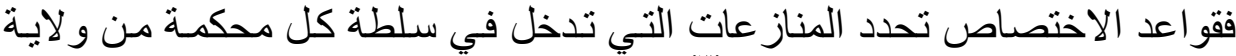

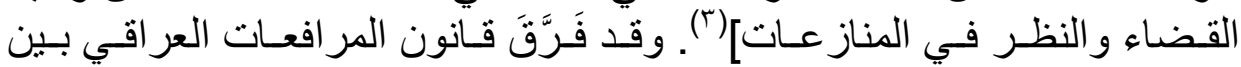

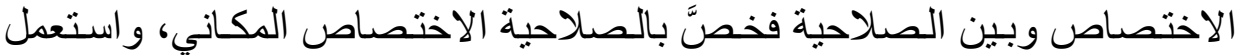

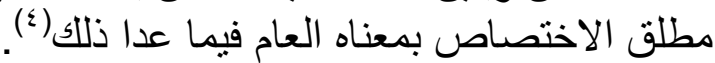

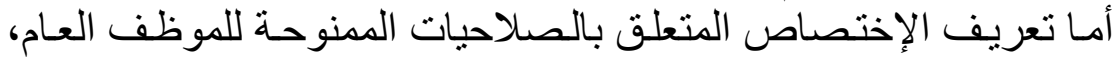

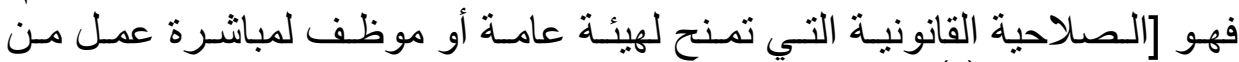

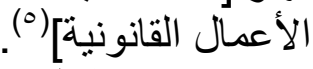

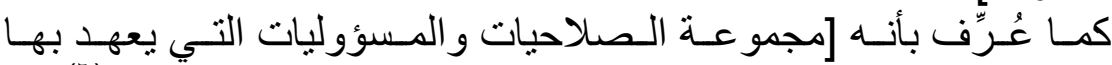

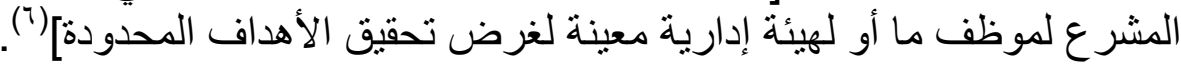

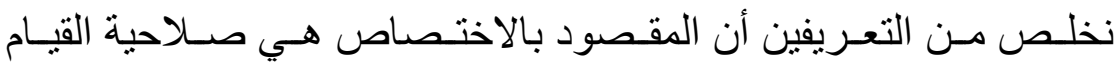

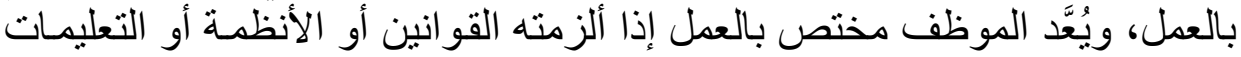

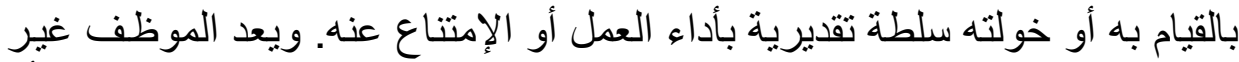

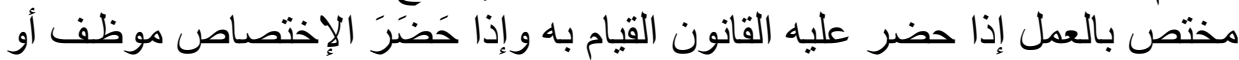

(') ينظر: إبن منظور، لسان العرب المحيط، المجلد الأول، دار لسان العرب، بيروت، بدون سنة طبع،

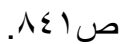
(؟) ينظر علي بن هاديـة وآخرون، القاموس الجديد للطلاب، الطبعة الثنانية، الشركة الوطنية للنشر

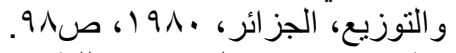

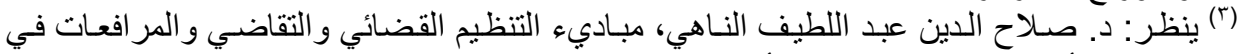

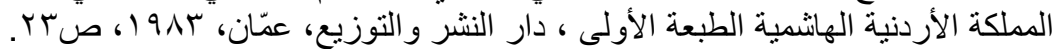

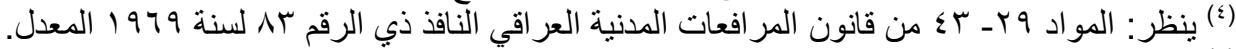

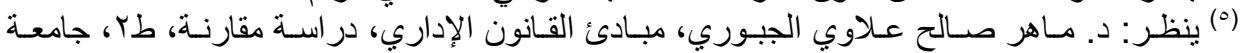

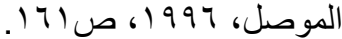

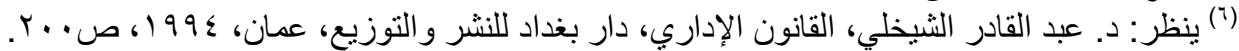


مـوظفين آخـرين، وَتحـدد القـو انين أو الأنظمـة أو التعليمـات الأعمـال التـي تـدخل

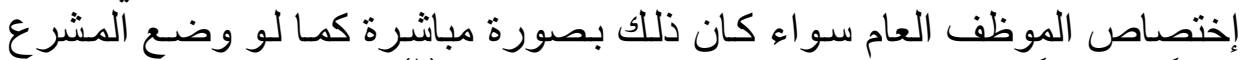

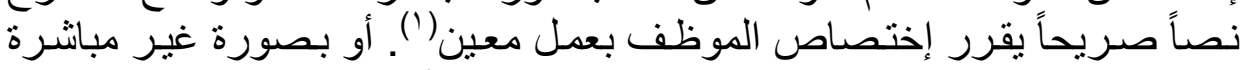

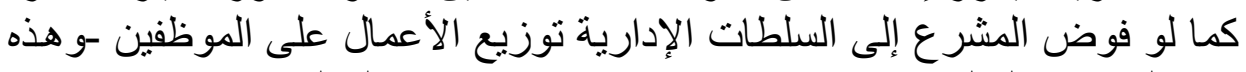

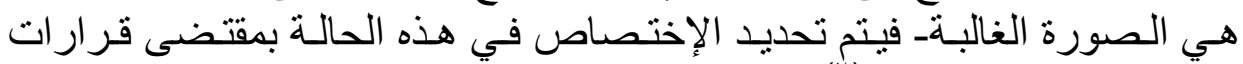

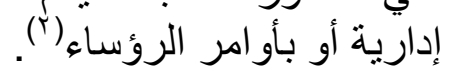

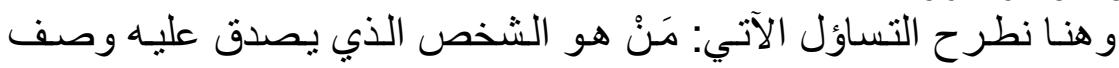

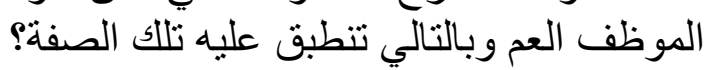

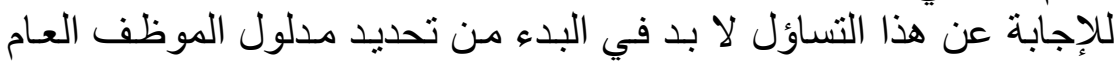

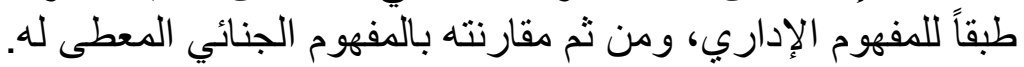

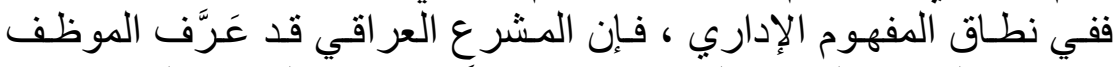

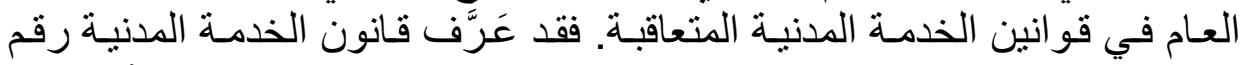

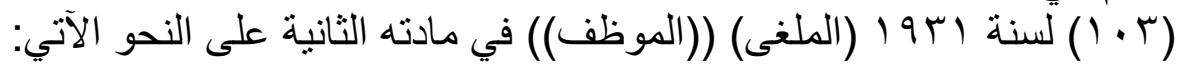

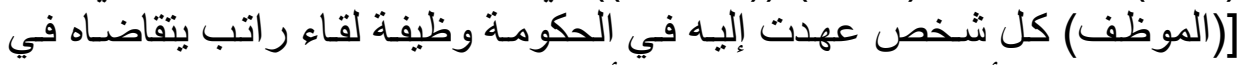
الميز انية العامة أو ميز انية خاصة ونابة وتابع لأحكام قانون التقاعد].

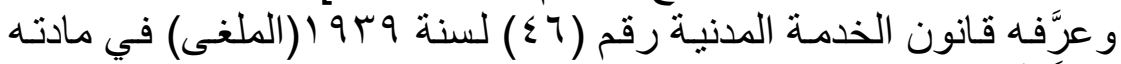

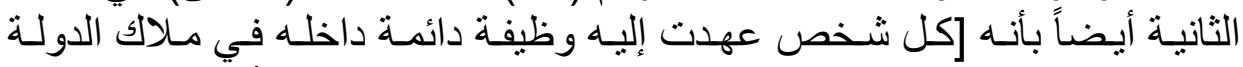

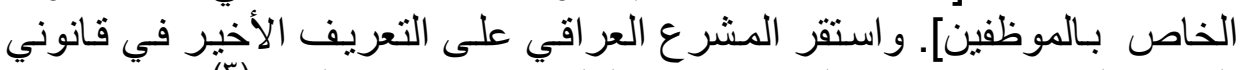

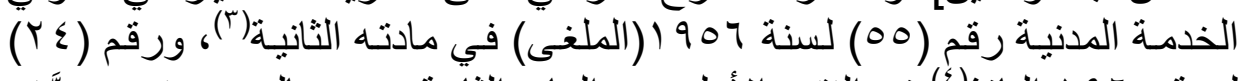

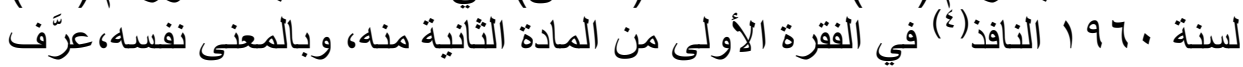

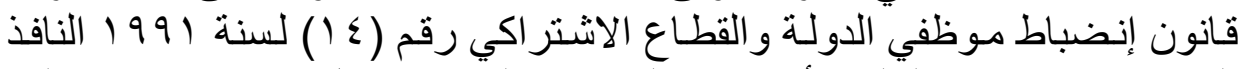

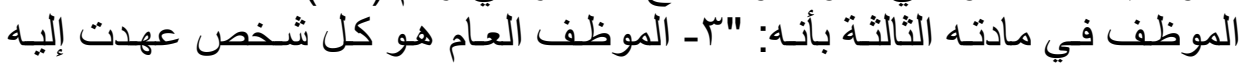

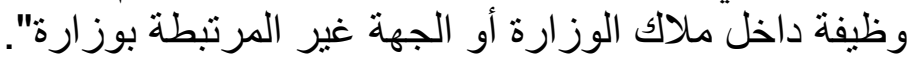

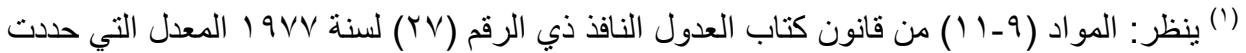

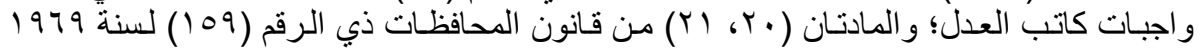

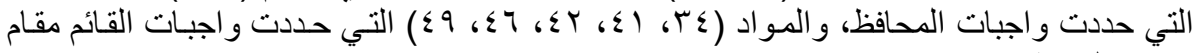
ومدير الناحية.

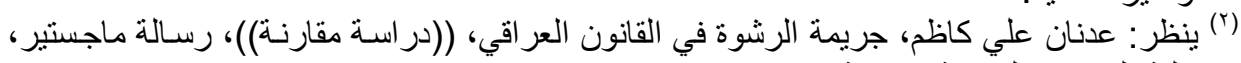

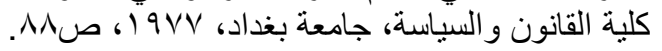

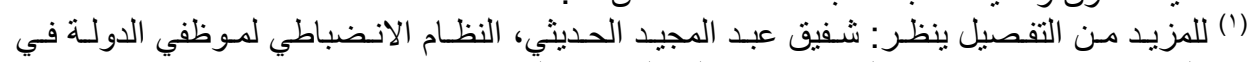

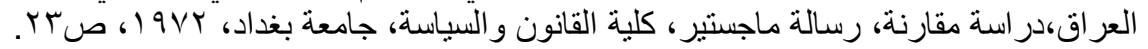

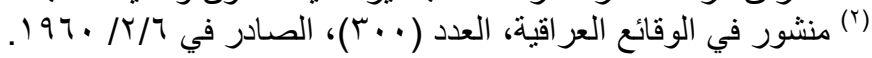




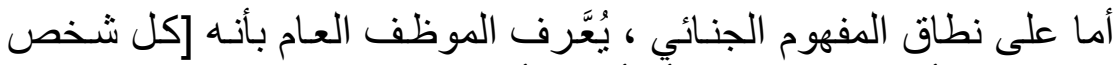

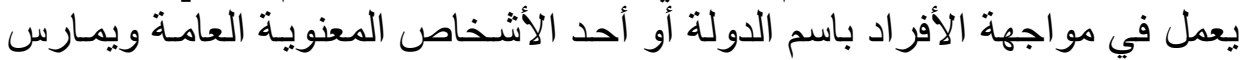

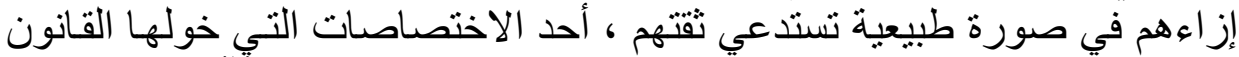

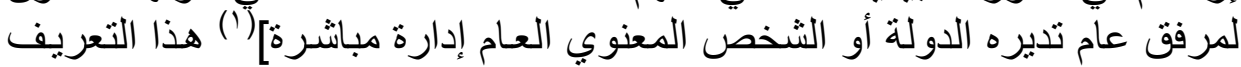

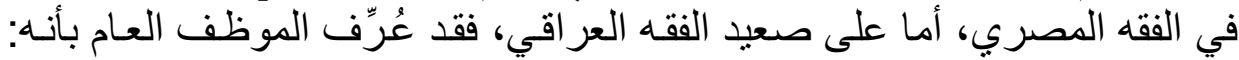

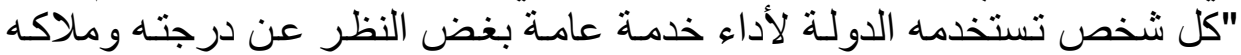

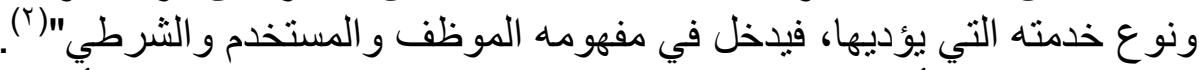

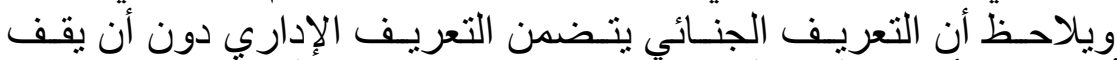

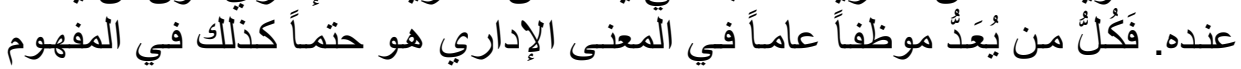

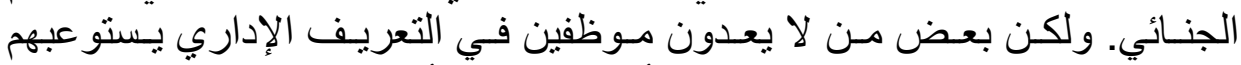

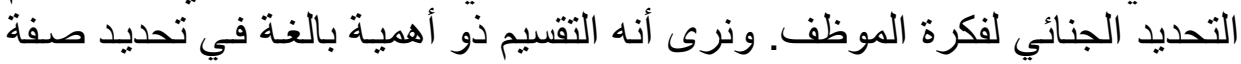

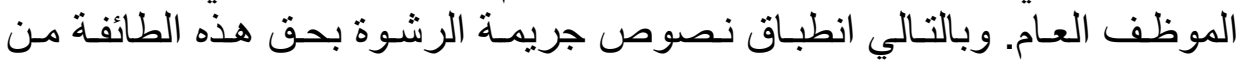
العاملين في الدولة دون غير هم.

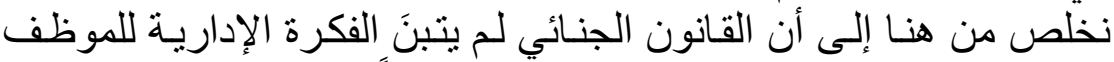

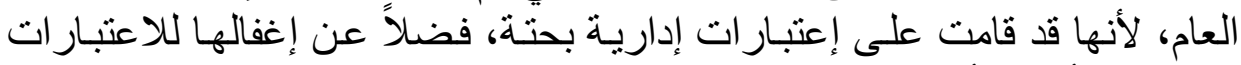

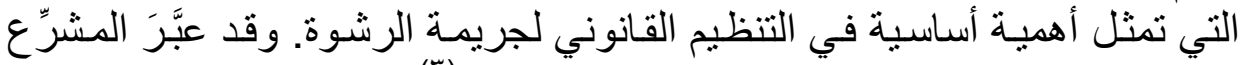

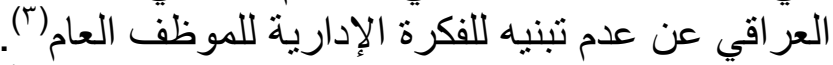

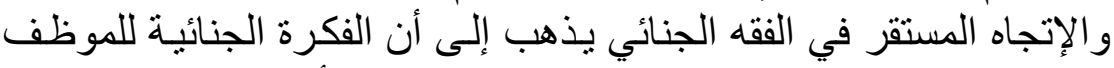

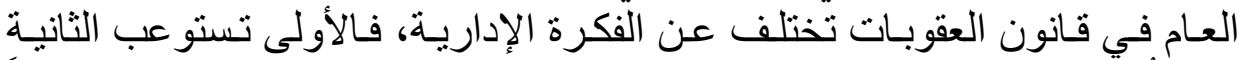

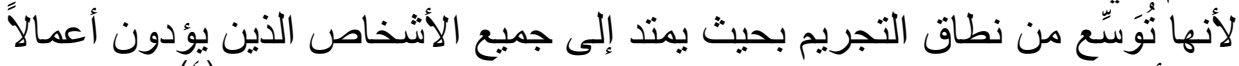

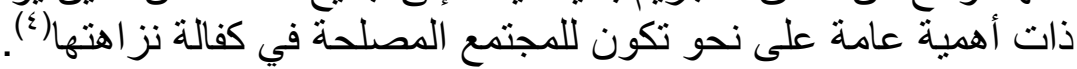

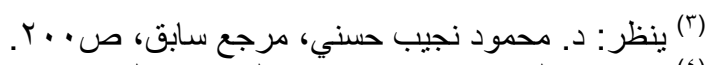

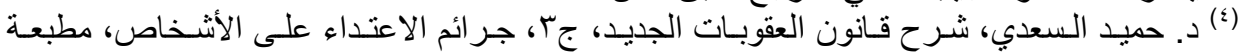

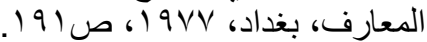

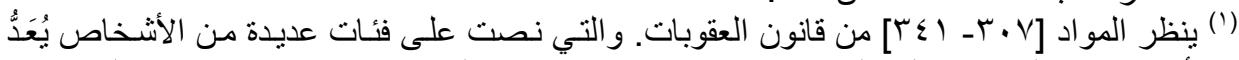

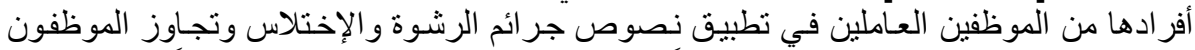

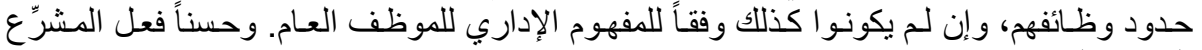

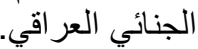
(r) وللمزيد من التفصيل حول هذين المفهومين- الإداري و الجنائي- ينظر: د. د. صباح مصباح محمود

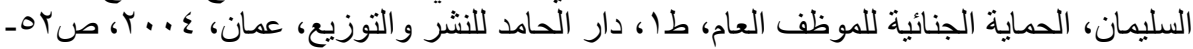

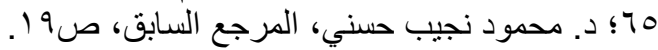


ويترتب على ذلك أن صفة الموظف العـام تمتد لتشمل الموظف الفعلي

وبالتـالي انطبـاق نـصوص القانون الخاصـة بالرشـوة بحقهـ في حسال إرتكابـه فعـلاً

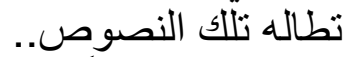

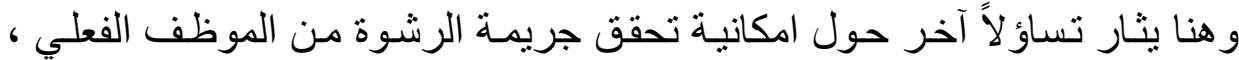

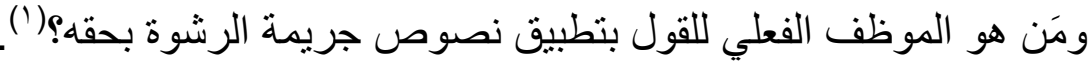
في الفقه الإداري الفرنسي يعرفه الفقيه مارسيل فالين (Marcel Waline)

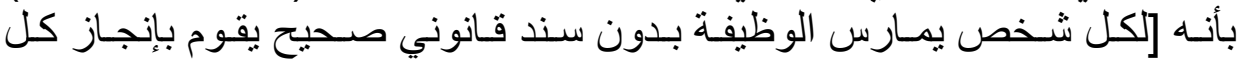
الأعمال المتعلقة بوظيفته].

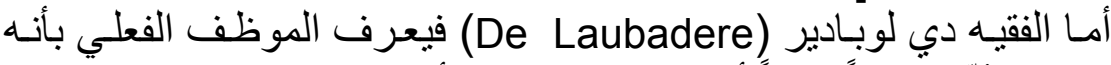

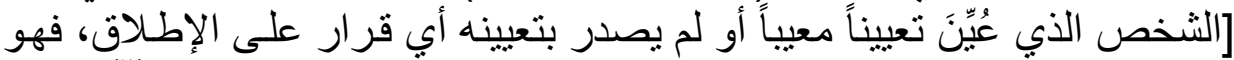

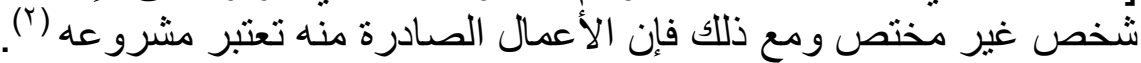

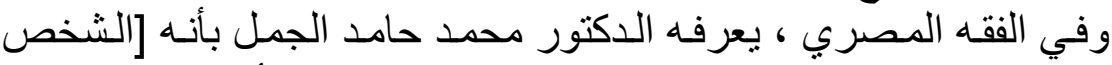

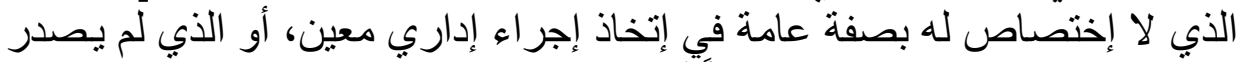

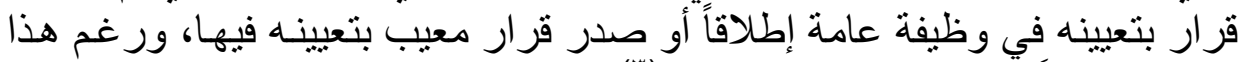

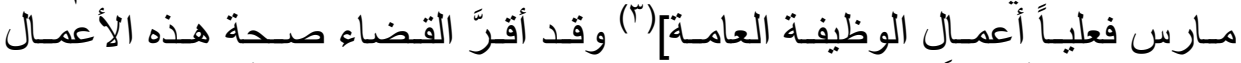

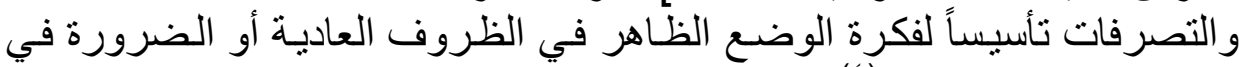

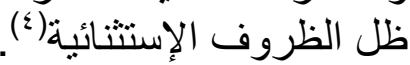

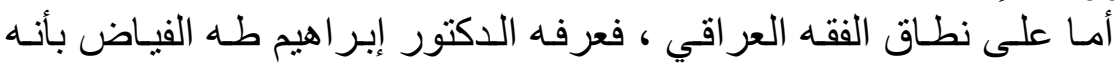

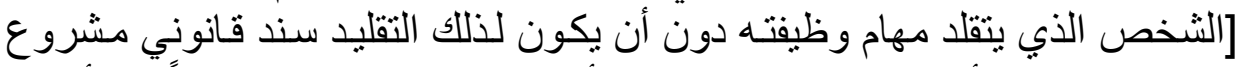

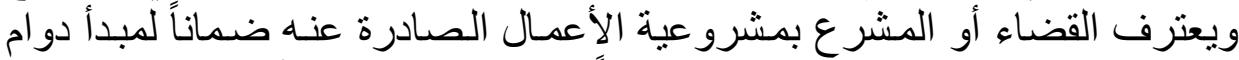

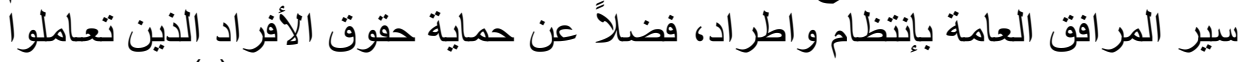
مع ذلك الثخص الثاغل للوظيفة بصورة غير مشرو عة بحسن نية] (0).

(")

(2) Marcel Waline/ Manuel Elementaire de Dort Administatif, 4 edition, Recueit,1 Surey, Paris, 1946, P. 350. ; De Laubadere/ Traite Dorit Administratif, 6 edition, Paris, 1973, P. 288.

نقـلاً عن:د. سليمان محمد الطماوي، مبادئ القانون الإداري، الكتاب الثناني، دار الفكر العربي،

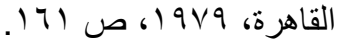

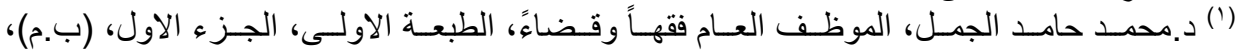
.0r. 0 (190V (r) (r) المصدر نفسه.

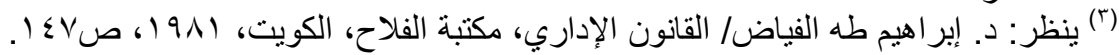


نخلص من التعريفات المتقدمة إلى أن الموظف الفعلي كمـا الموظف العـام

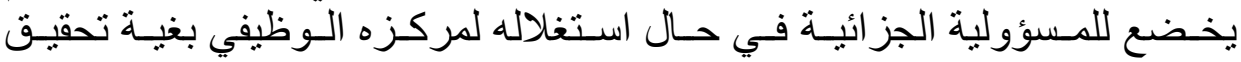

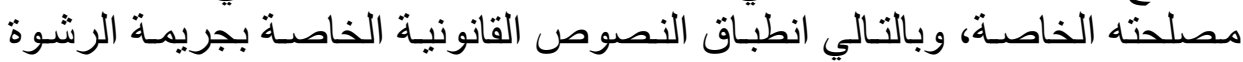
بحقه.

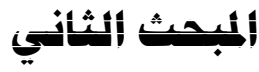

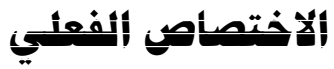

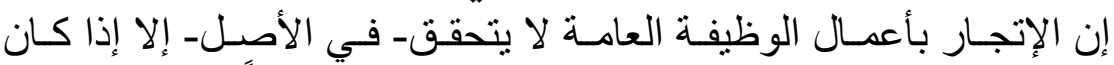

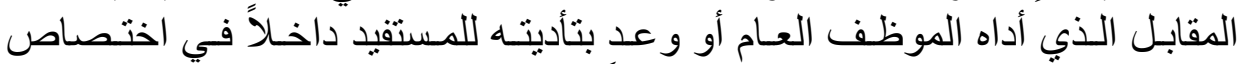

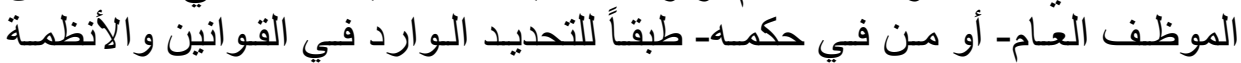

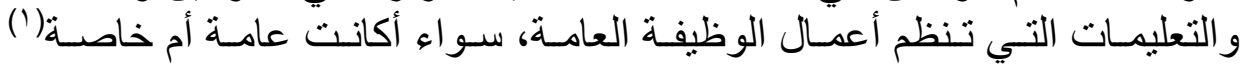

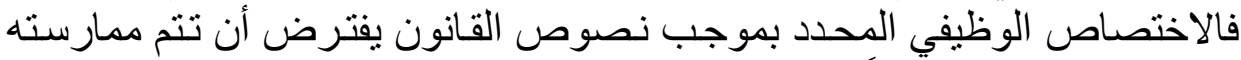

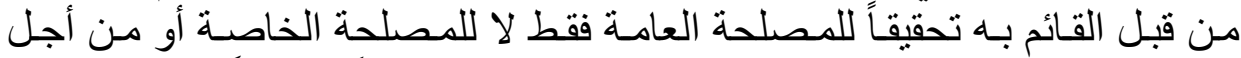

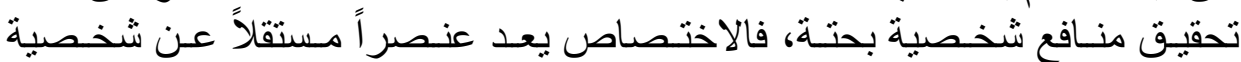

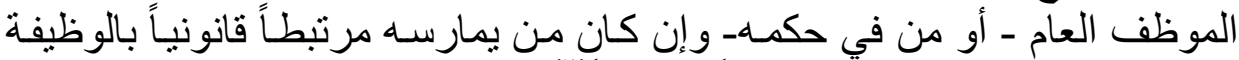

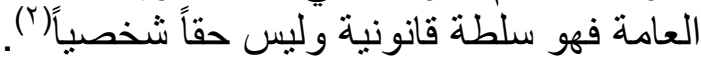

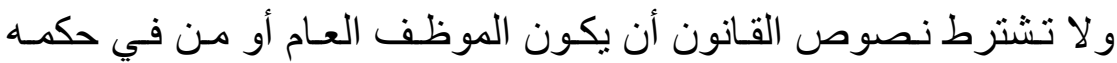

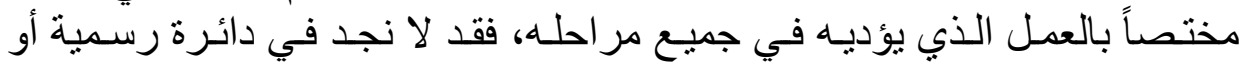

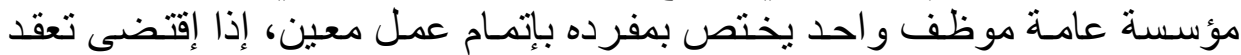

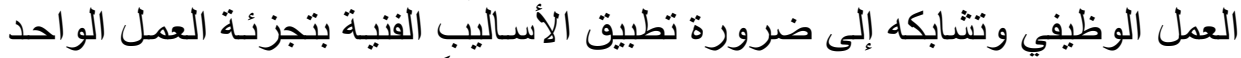

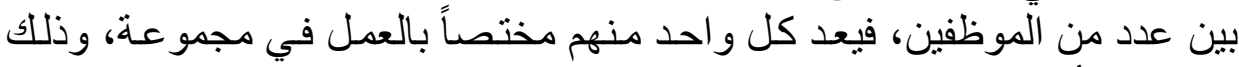

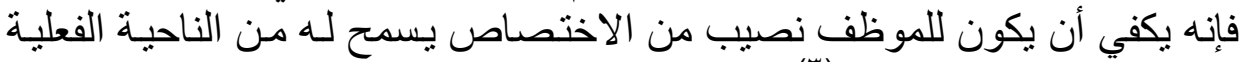

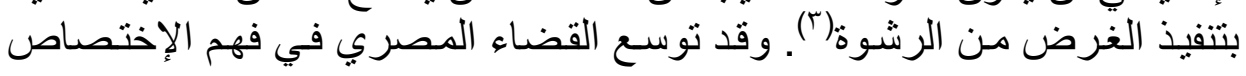

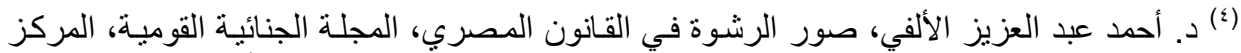

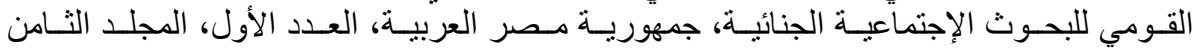

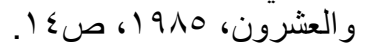

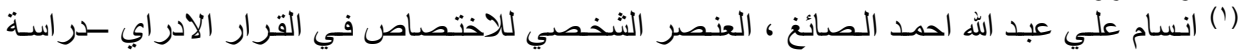

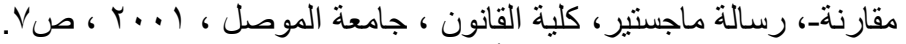

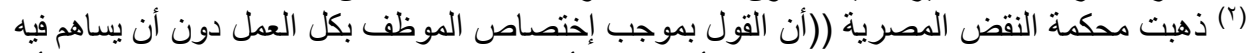

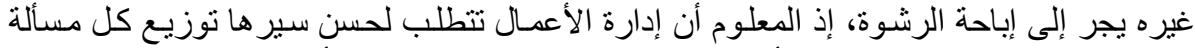

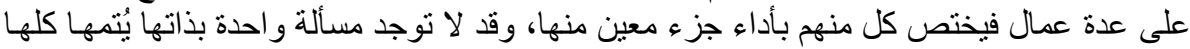

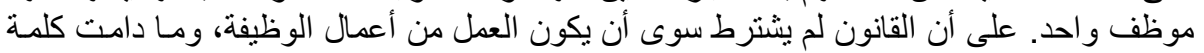




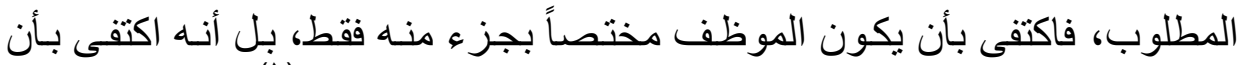

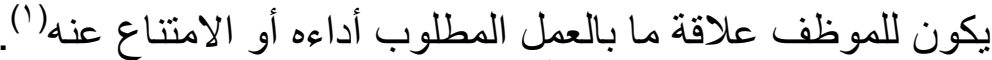

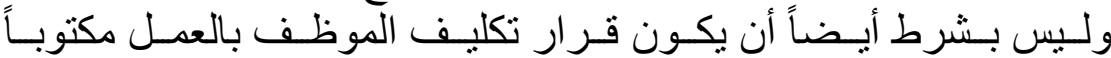

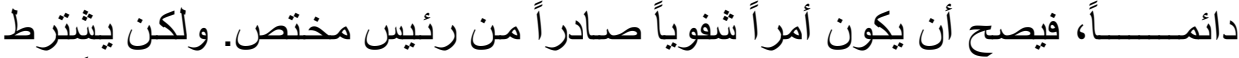

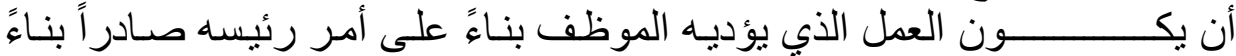

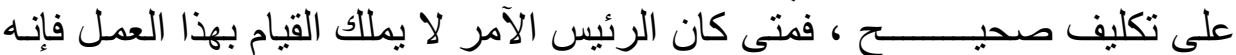

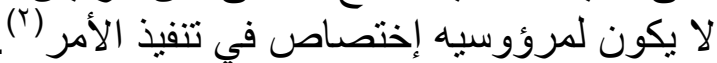

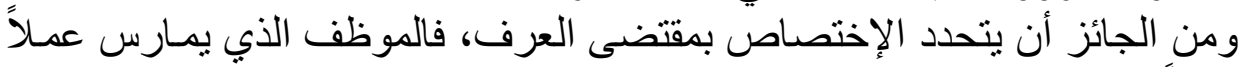

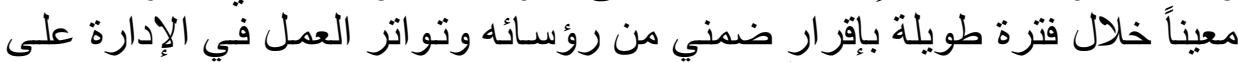

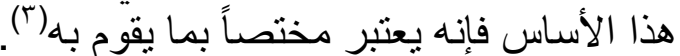

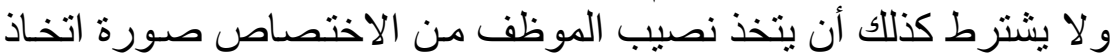

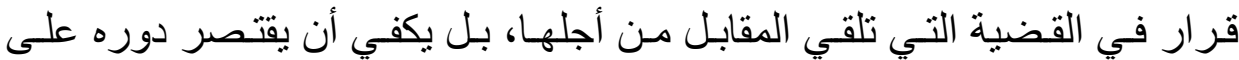

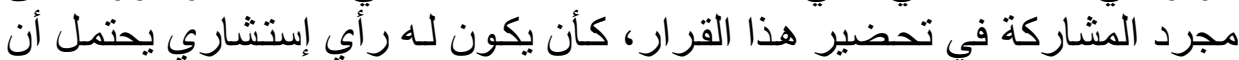

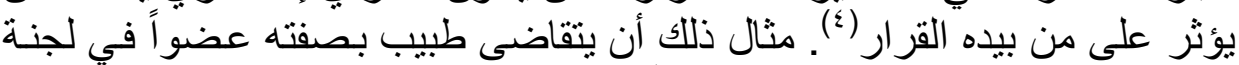

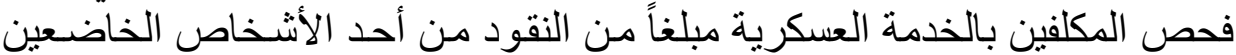

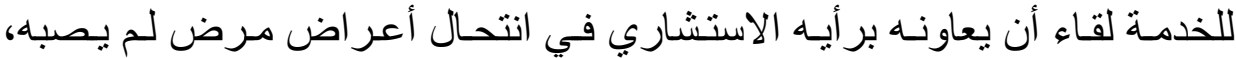

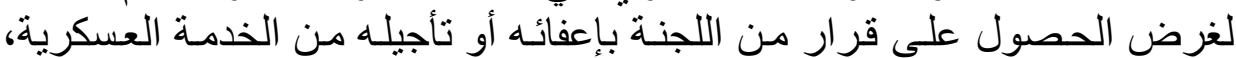

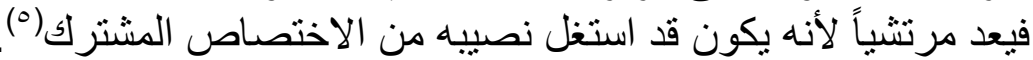

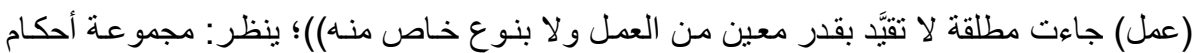

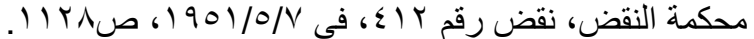

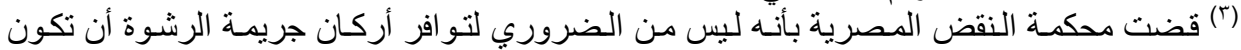

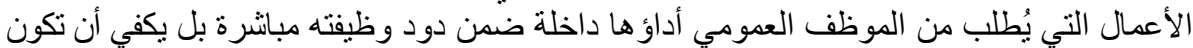

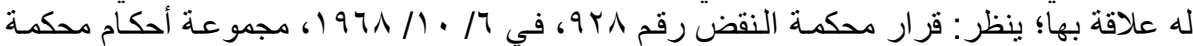

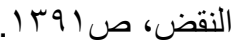

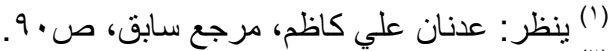

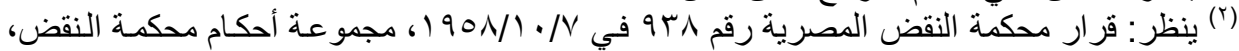

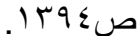
(†) ينظر : د. محمود نجيب حسني، شرح قانون العقوبات- القسم الخاص- الجر ائم المضرة بالمصلحة

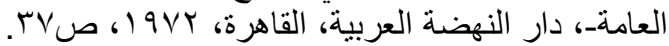

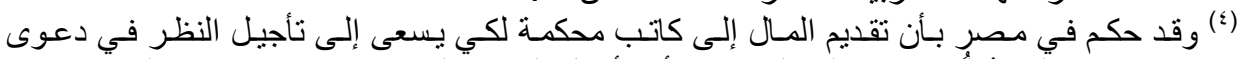

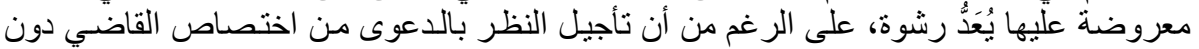

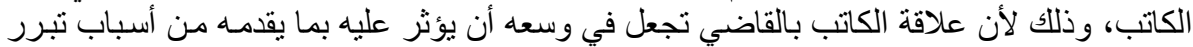

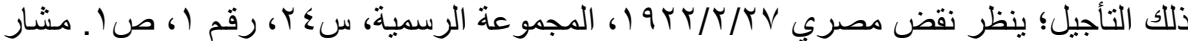

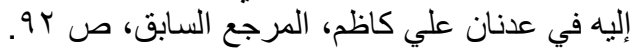




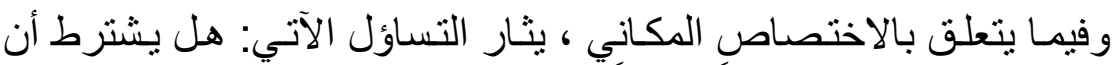

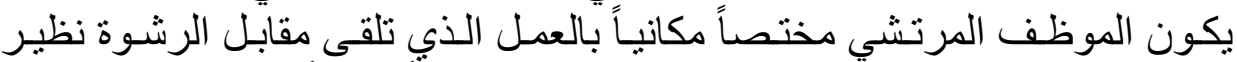

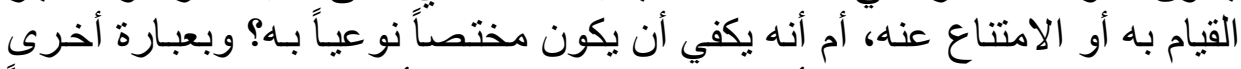

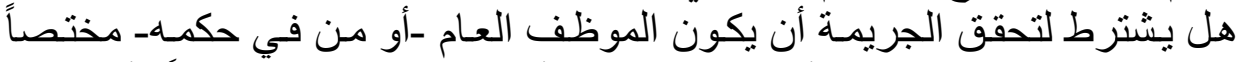

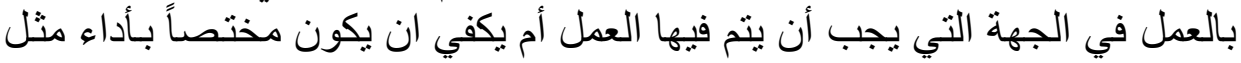

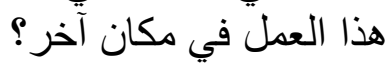

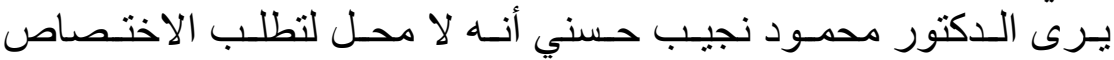

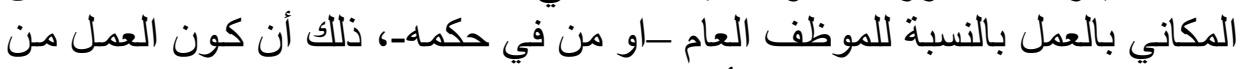

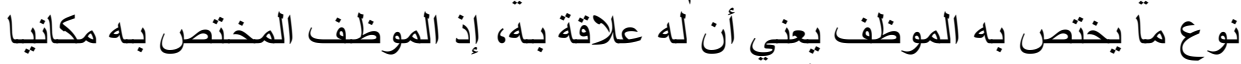

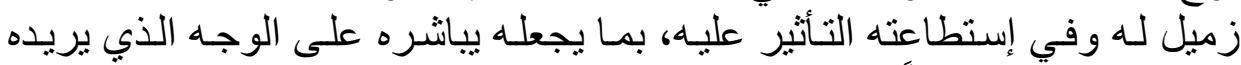

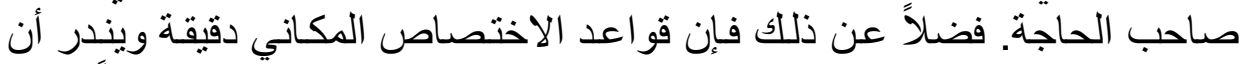

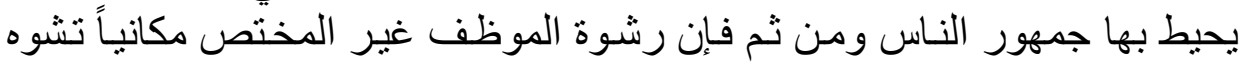

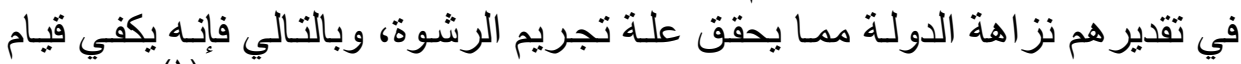

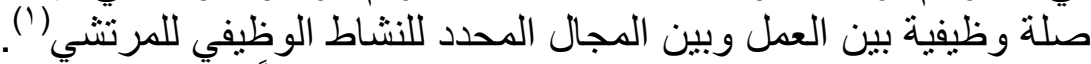

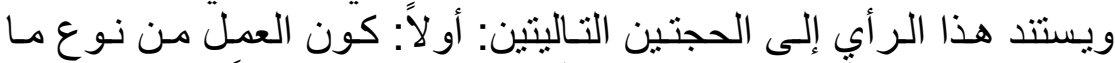

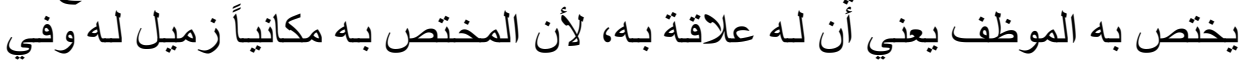

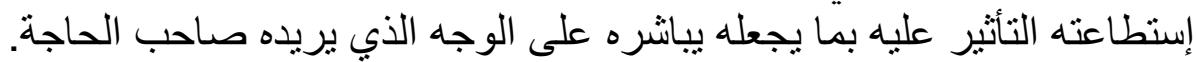

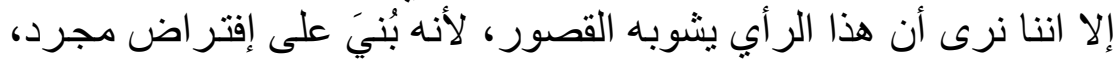

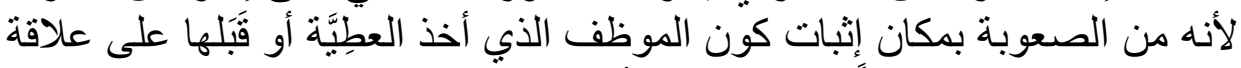

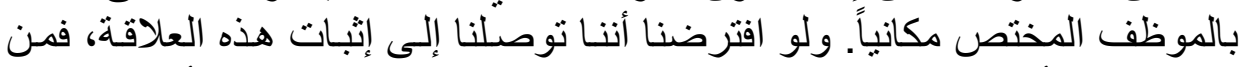

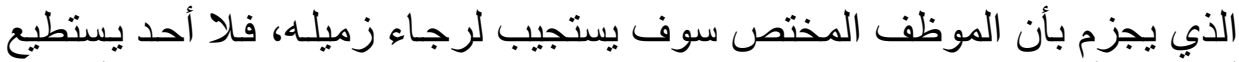

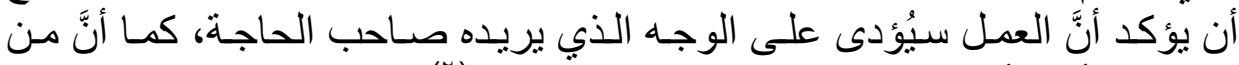

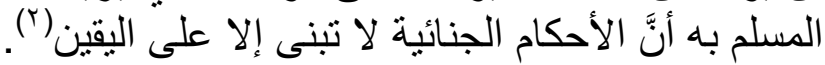

(') ينظر : د. محمود نجيب حسني/ شرح قانون العقوباتـ القسم الخاص- الجر ائم المضرة بالمصلحة

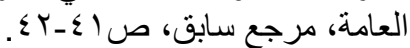

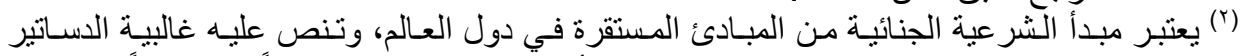

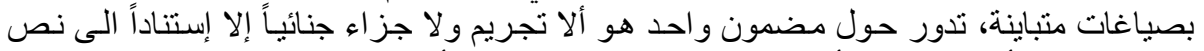

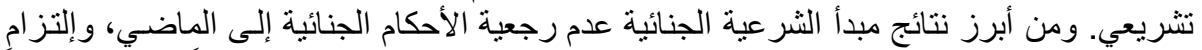

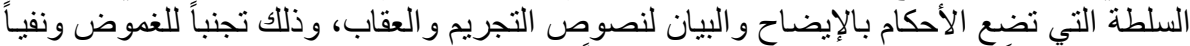

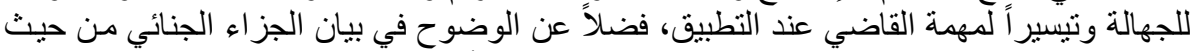

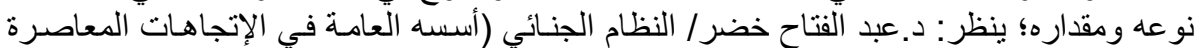

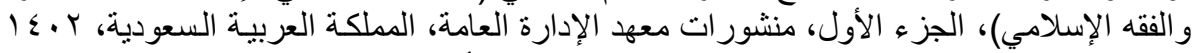

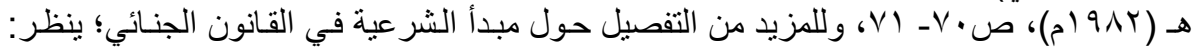


و القول بغير ذلك يحمل النص أكثر مما يحتمل. إذ حتى لو سلمنا جدلاً بأن

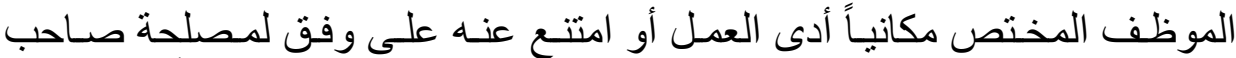

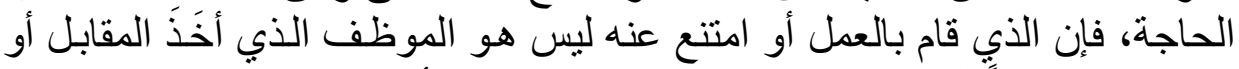

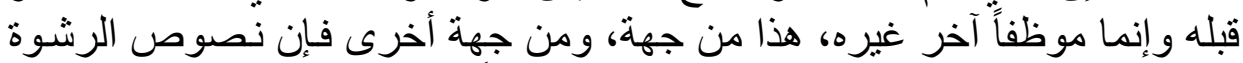

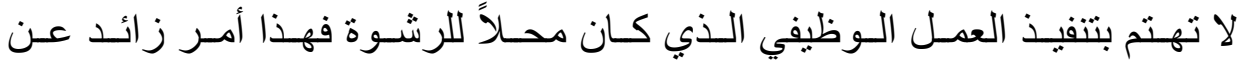

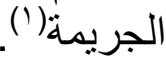

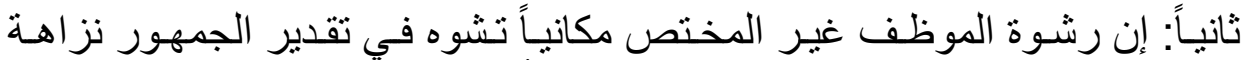

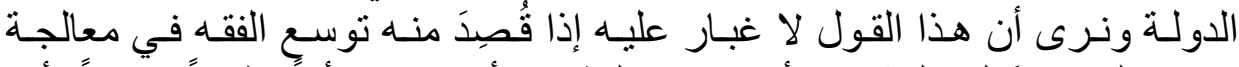

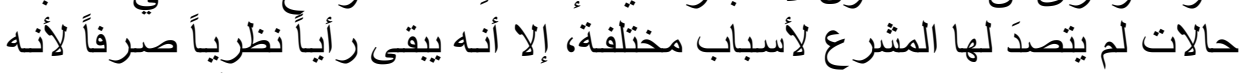

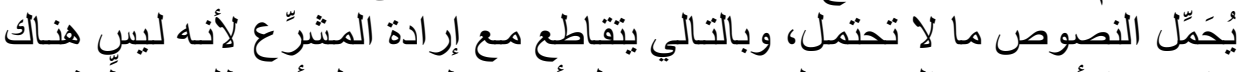

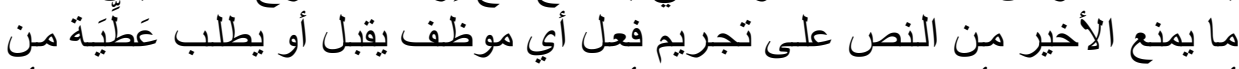

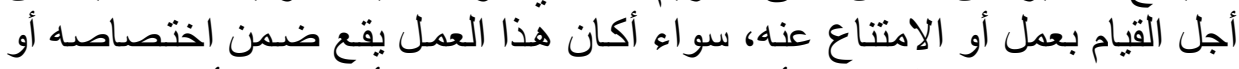

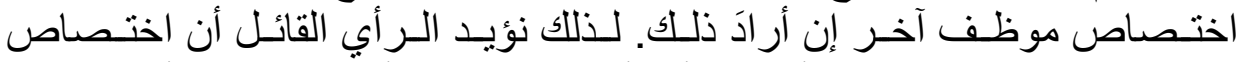

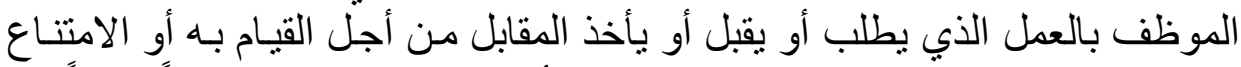

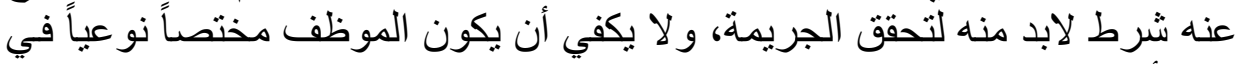

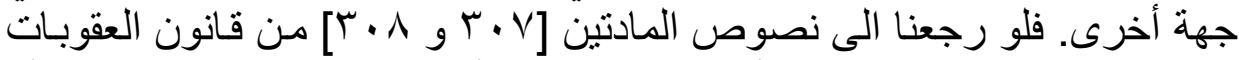

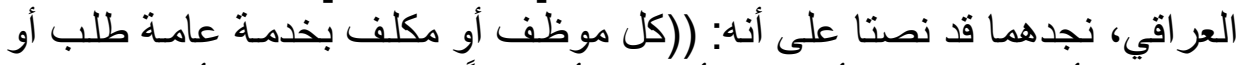

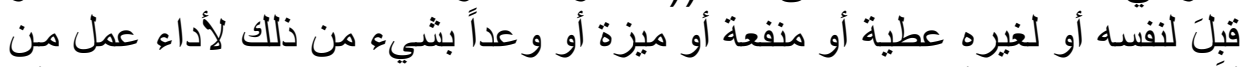

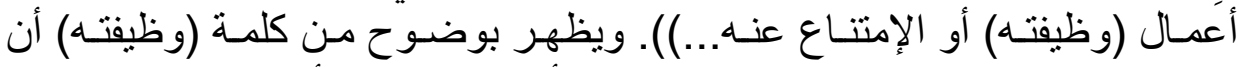

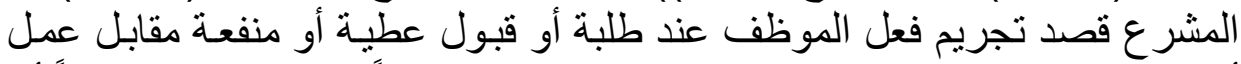

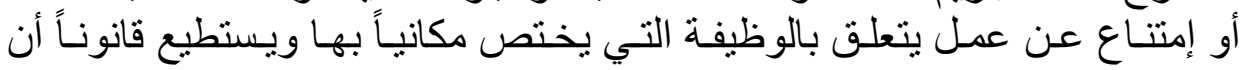
يباشر ها.

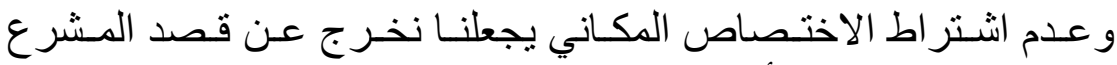

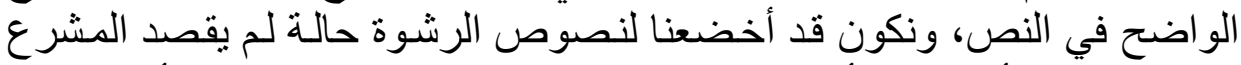

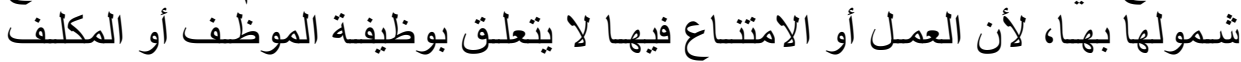

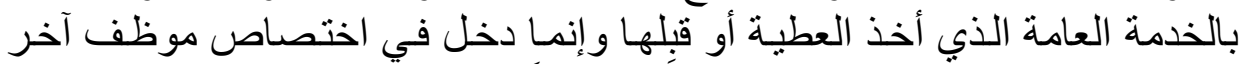

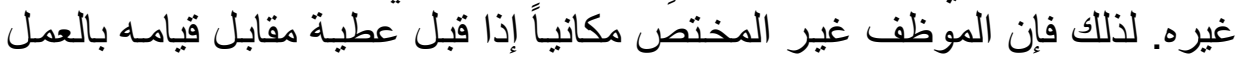

طلال عبد حسين البدر انيـ الشرعية الجز ائيةــ در اسـة مقارنـة، أطروحـة دكتور راه، كلية القانون،

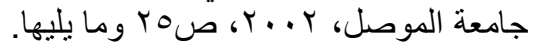
(') ينظر : د. عبد المهيمن بكر سالم/ القسم الخاص في قالنون العقوبات، دار النهضة العربية، القاهرة، 


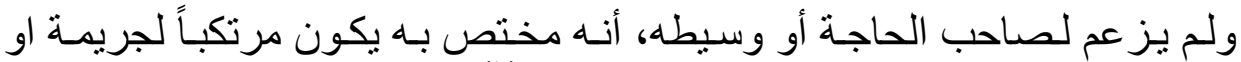

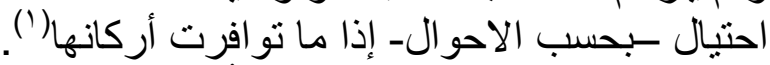

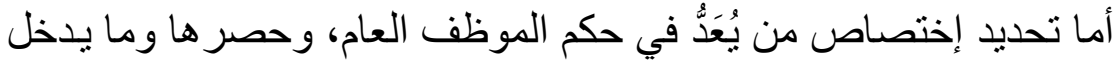

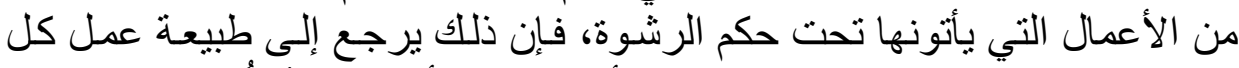

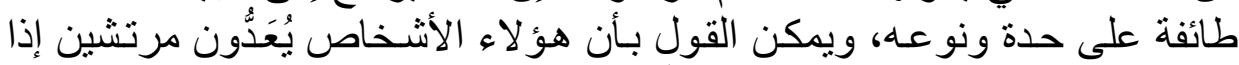

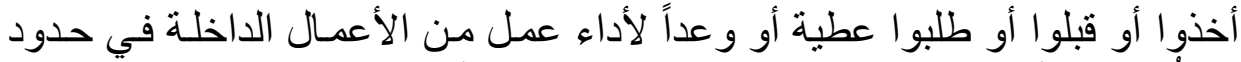

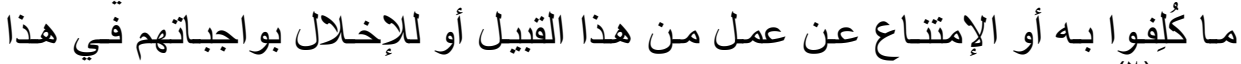

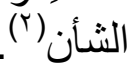

و الركن المادي في جريمة الرشوة يكتمل بمجرد قبول الموظف العطية أو أو الوبه

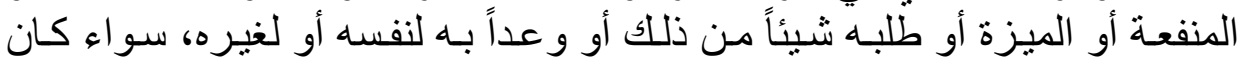

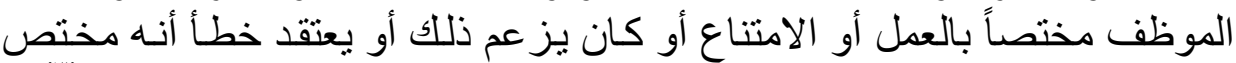

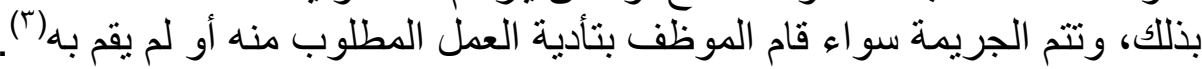

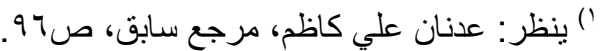

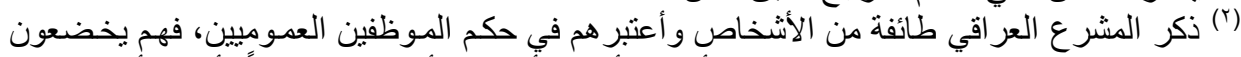

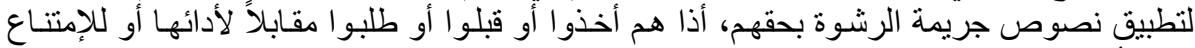

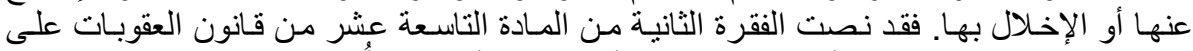

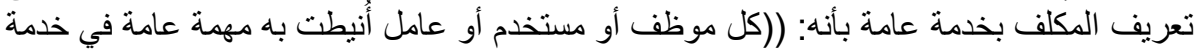

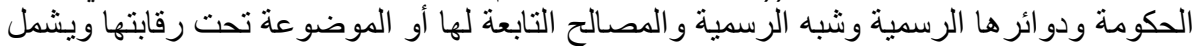

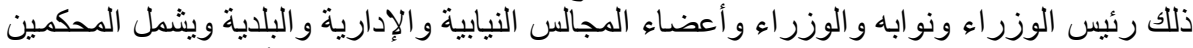

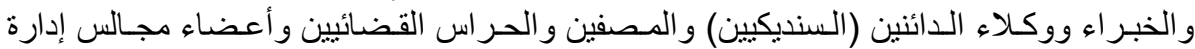

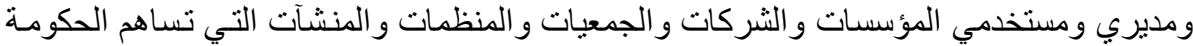

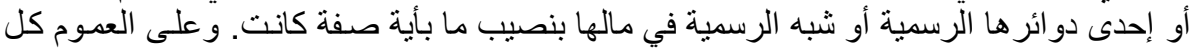

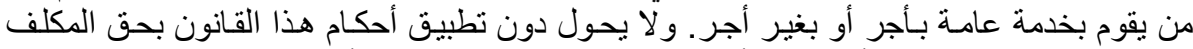

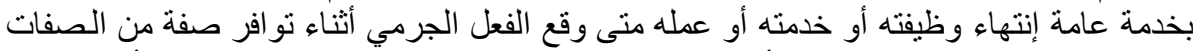

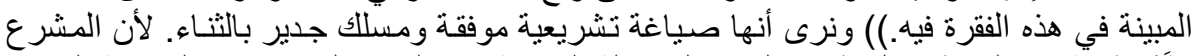

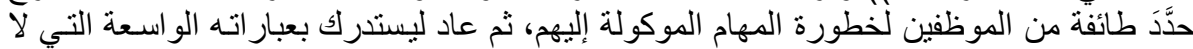

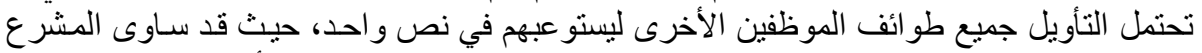

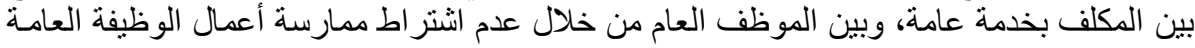

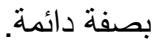

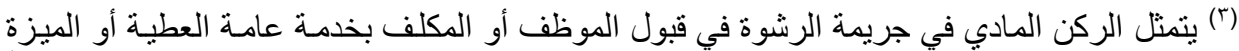

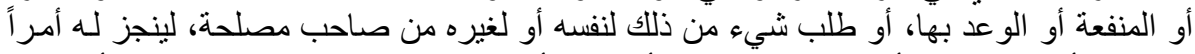

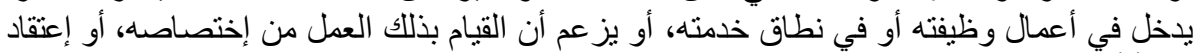
$==$

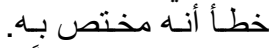

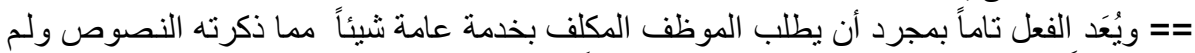

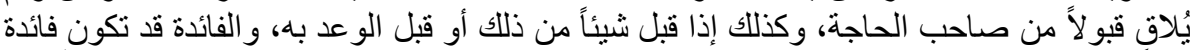

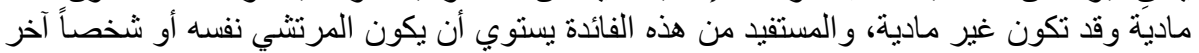




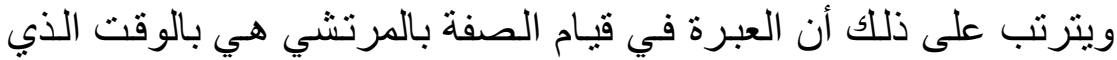

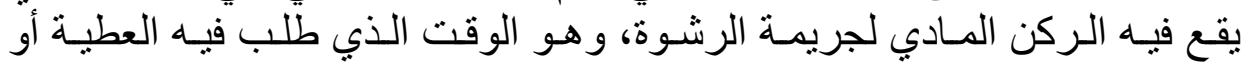

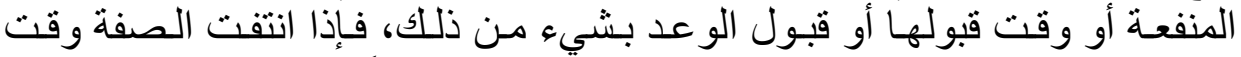

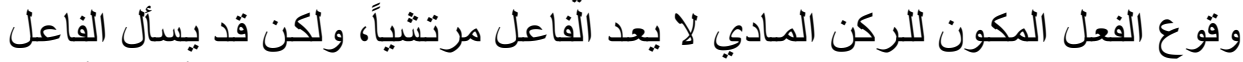

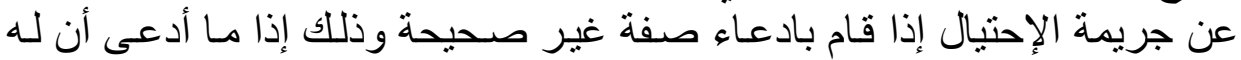

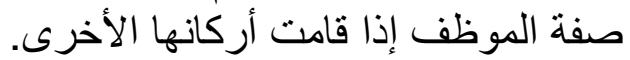

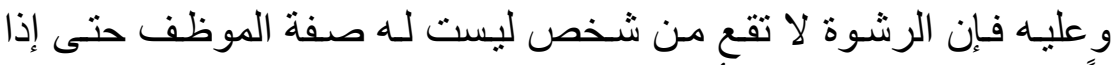

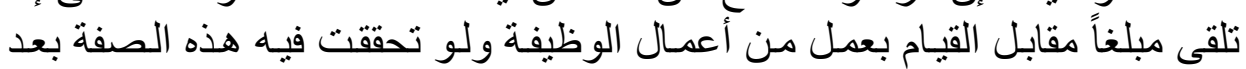

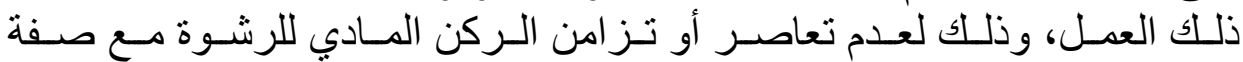

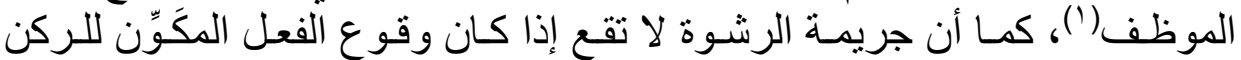

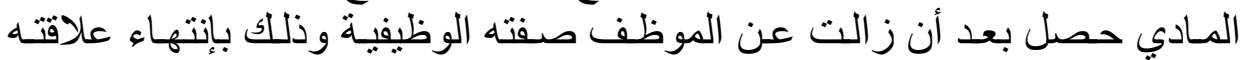

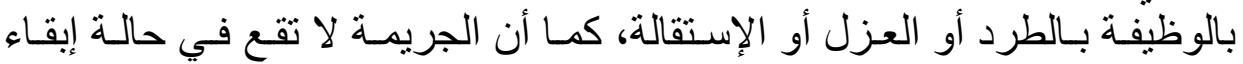

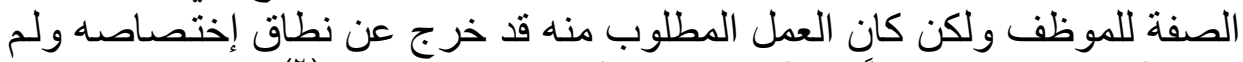

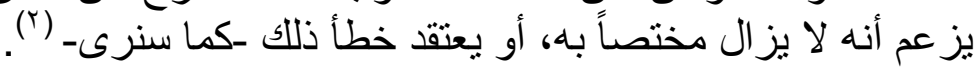

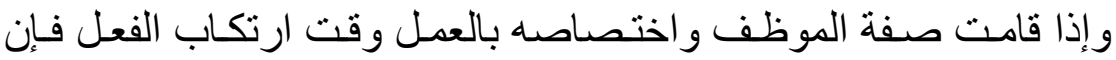

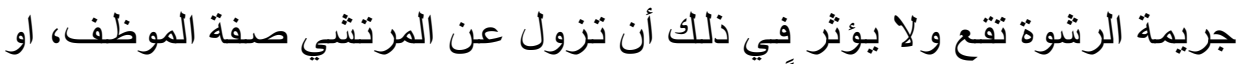

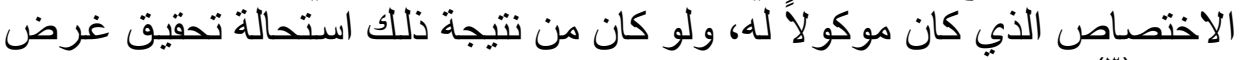

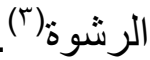

وتطبق نصوص الرشوة كذللك على مـن يقحم نفسه على الإدارة فيباثـر

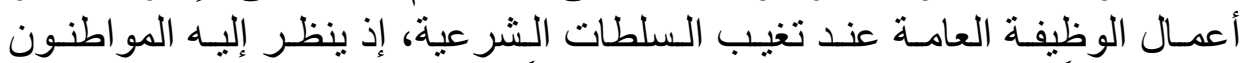

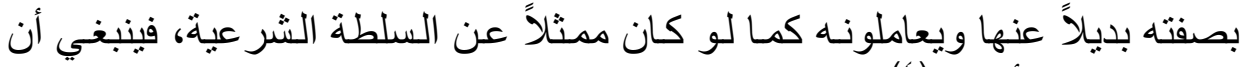

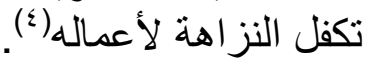

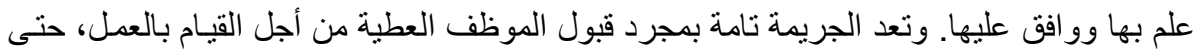

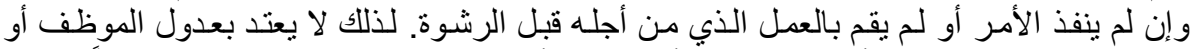

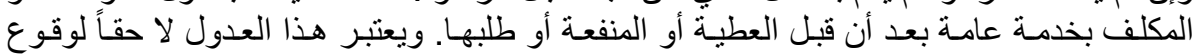

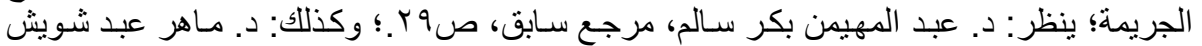

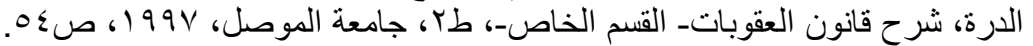

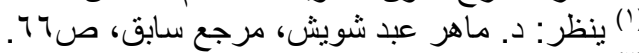

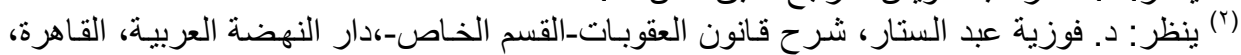

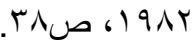

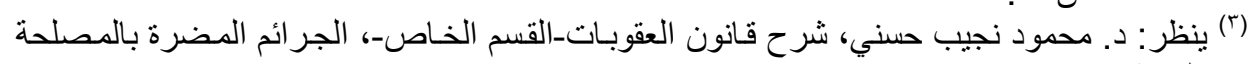

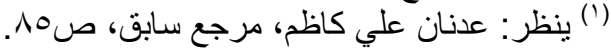


ذلك أن العلة من تجريم الرشوة هي الإتجـار بالوظيفـة العامـة أو استخلالكها

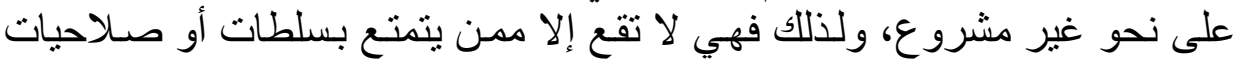

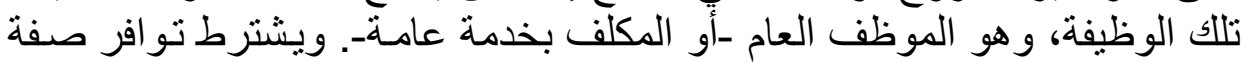

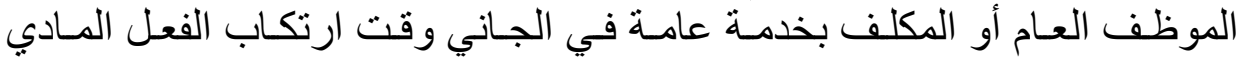

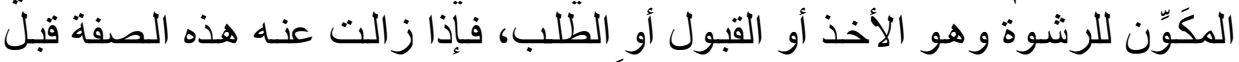

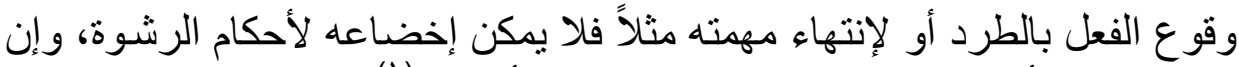

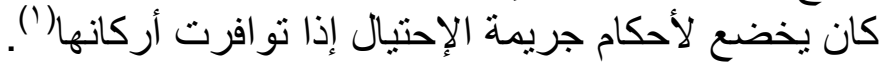

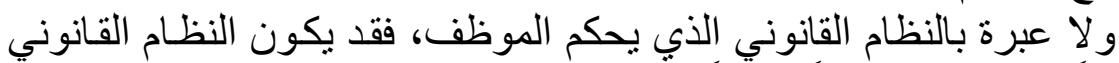

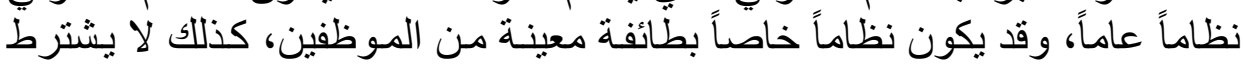

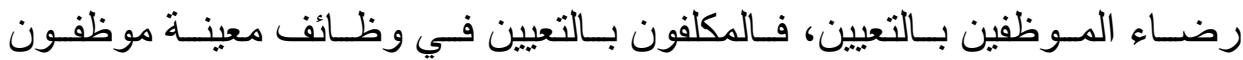

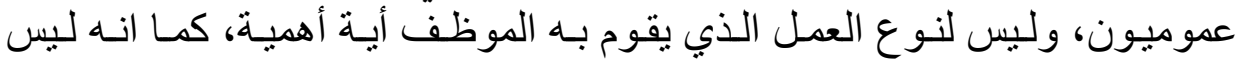

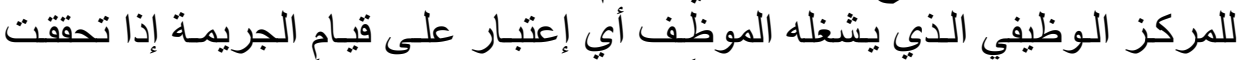

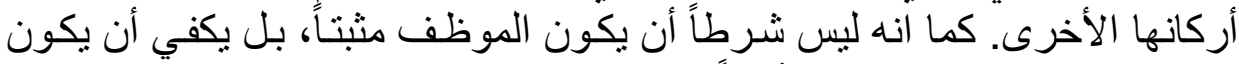

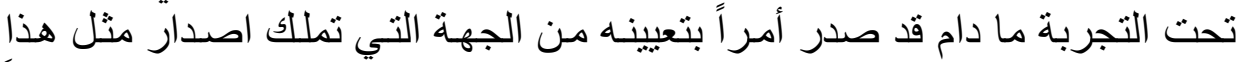

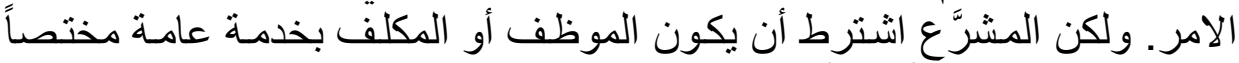

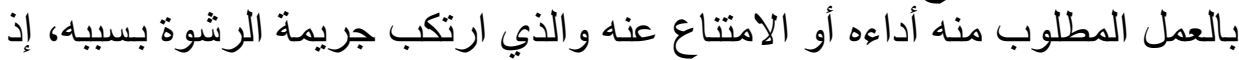

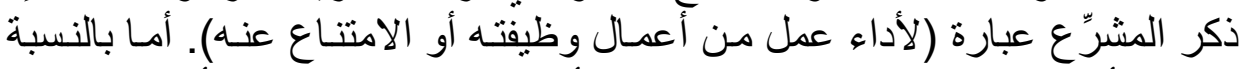

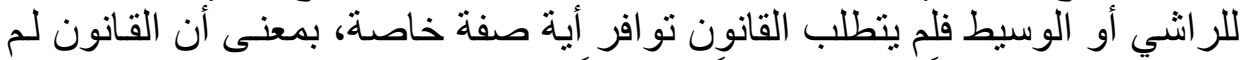

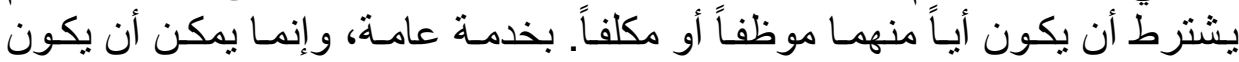

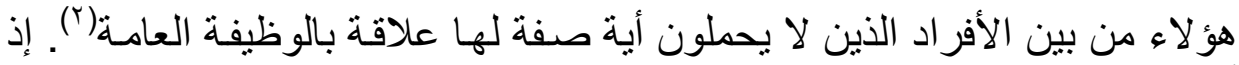

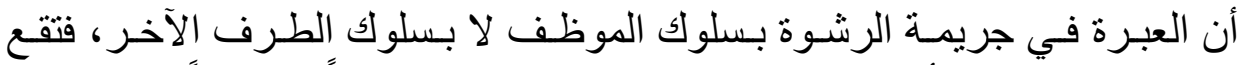

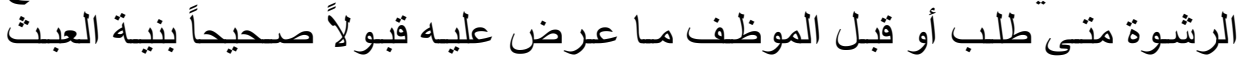

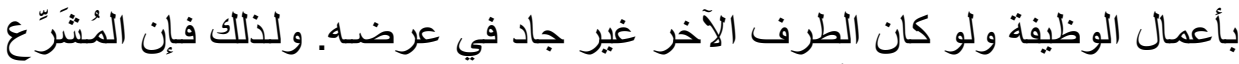

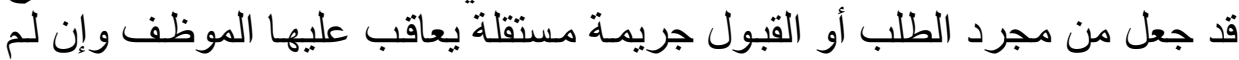

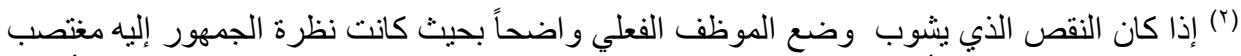

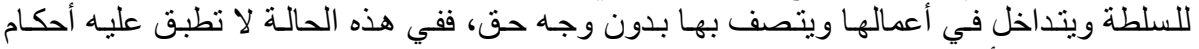

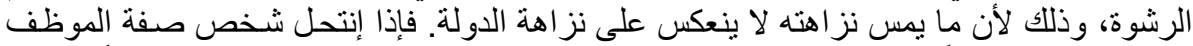

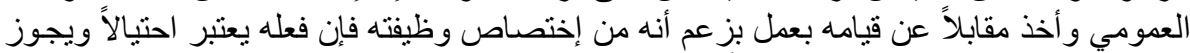

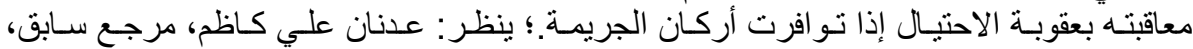

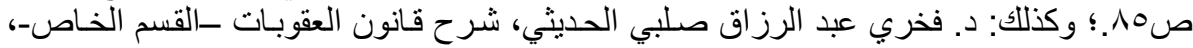

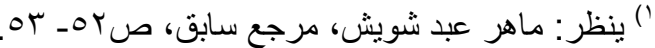


تتم الصفقة، و هذا يؤكد قيام جريمة الرشوة متى إرتكب الموظف أو المكلف بخدمـة

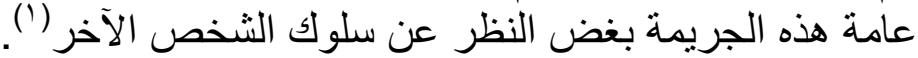

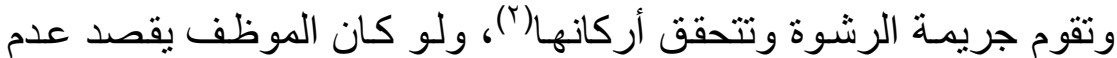

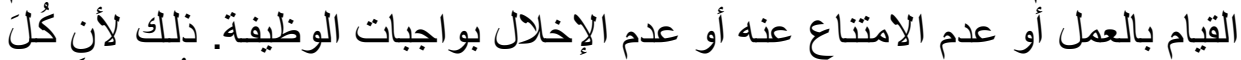

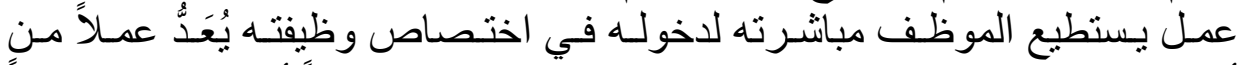

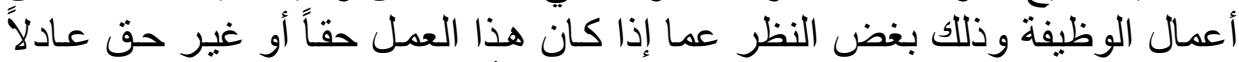

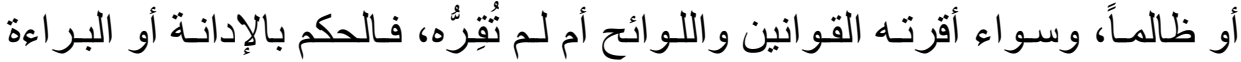

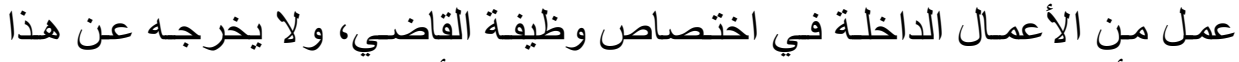

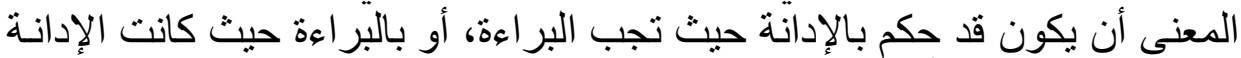

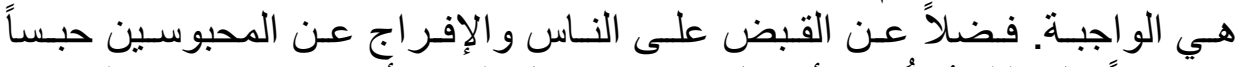

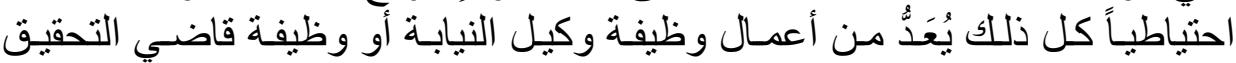

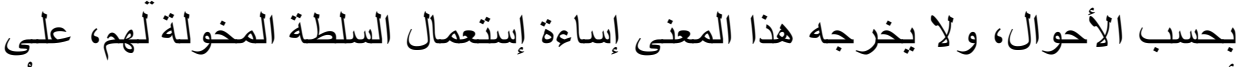

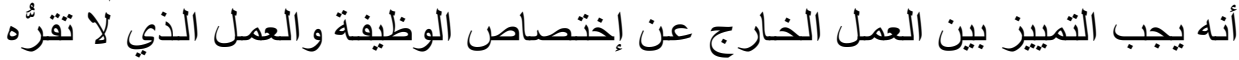

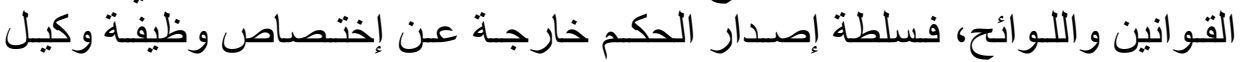

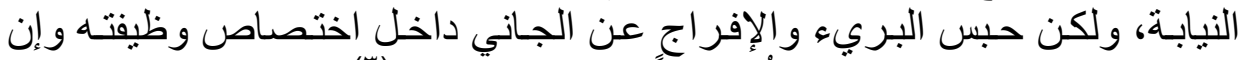

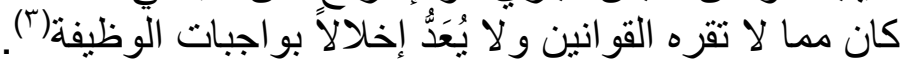

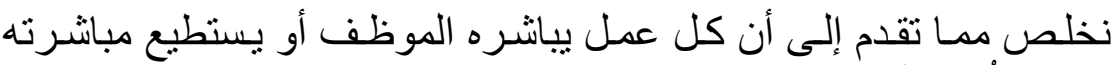

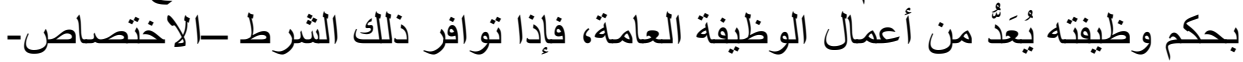

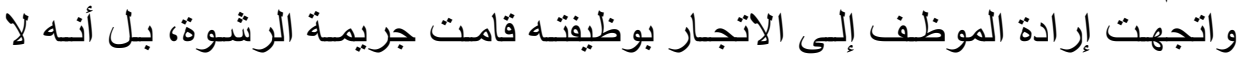

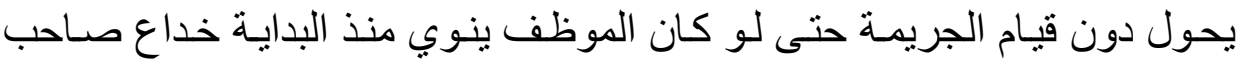

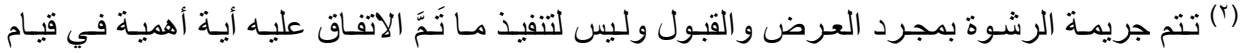

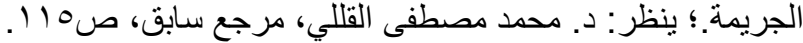

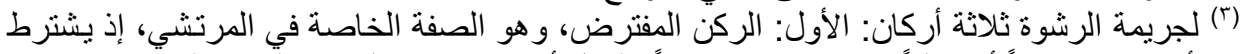

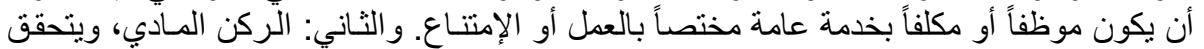

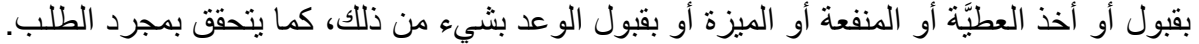

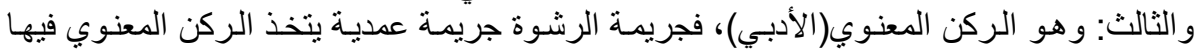

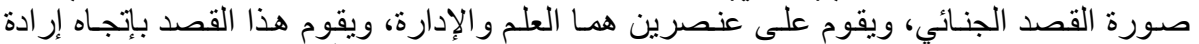

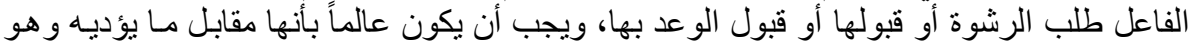

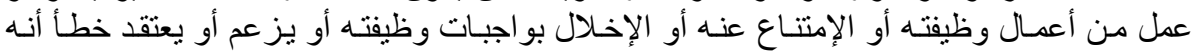

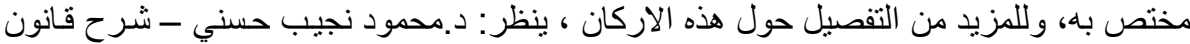

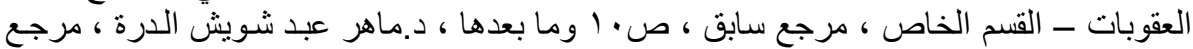
سابق ، 9 ؛ وما بعدها.

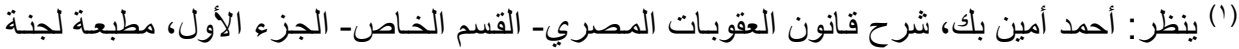

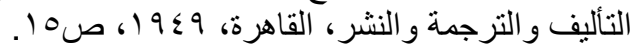




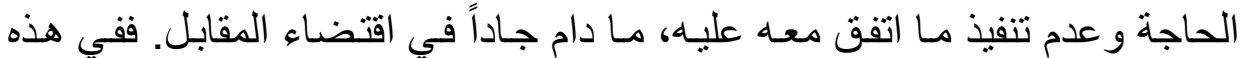

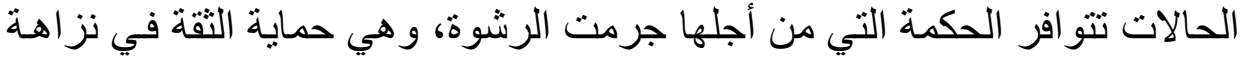
الموظف العام.

\section{|ctiliti}

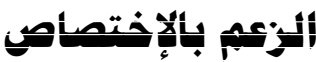

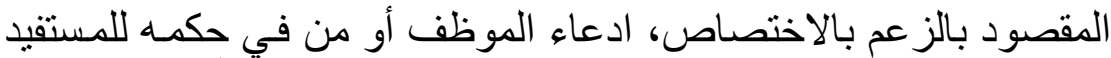

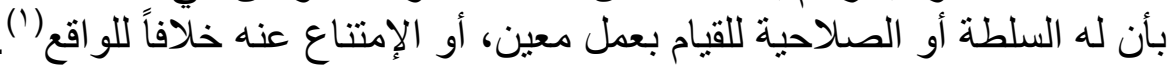

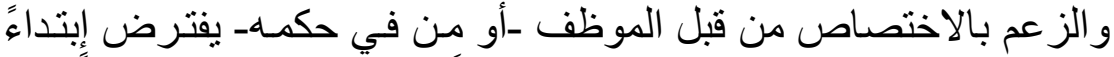

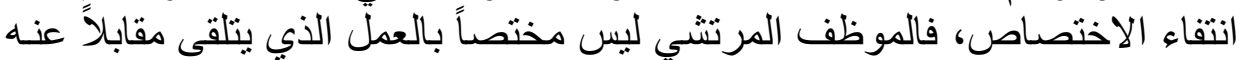

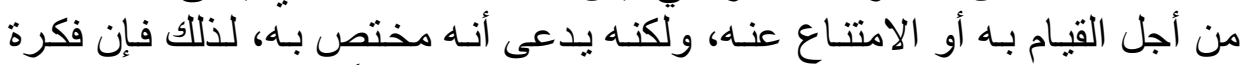

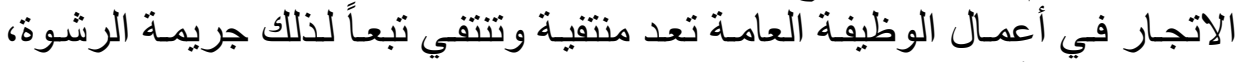

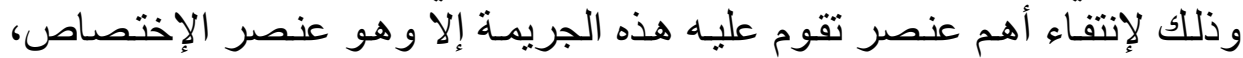

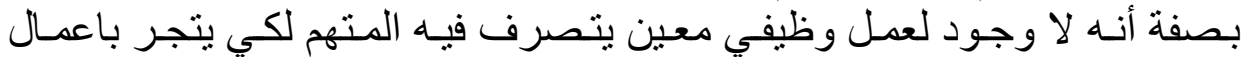

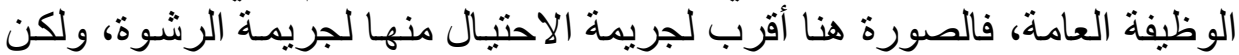

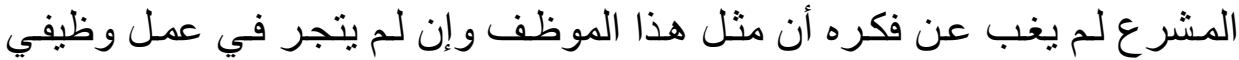

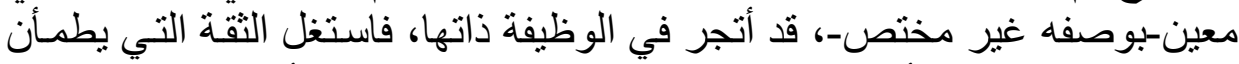

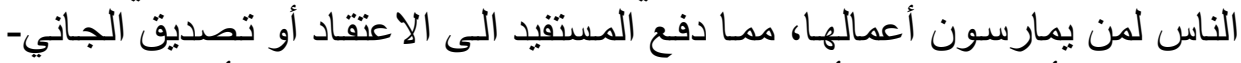

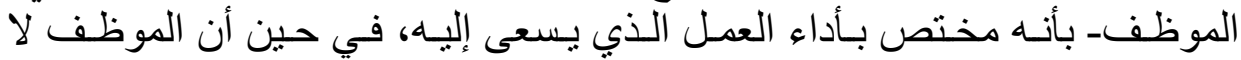

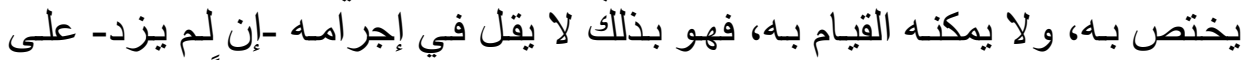

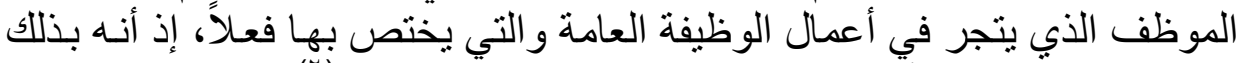

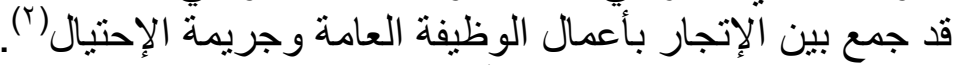

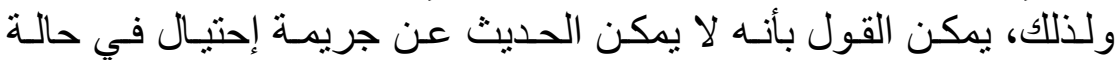

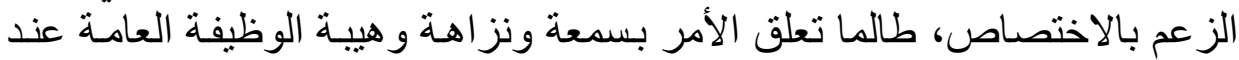

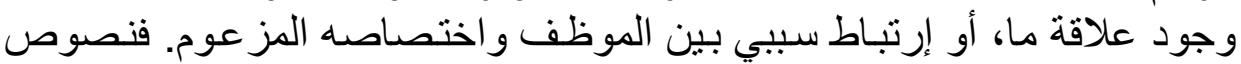

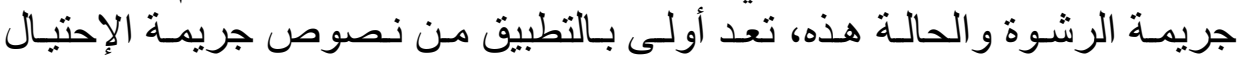

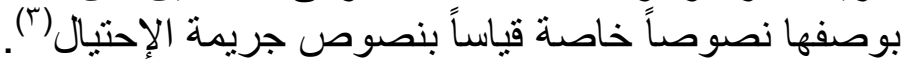

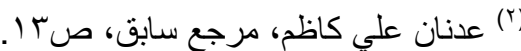

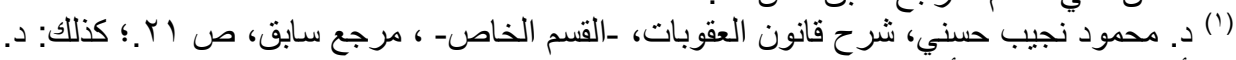

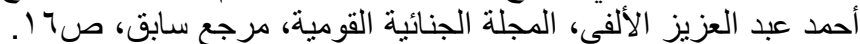

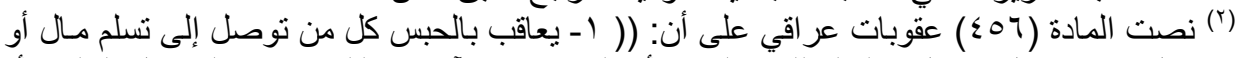

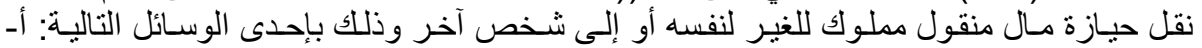


فجريمة الرشوة لا يعد فيها التسليم ركناً أساسياً، فمن الممكن أن يقتصر

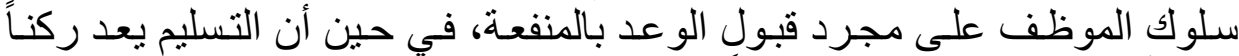

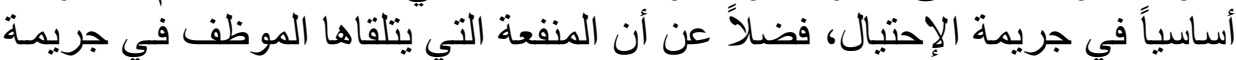

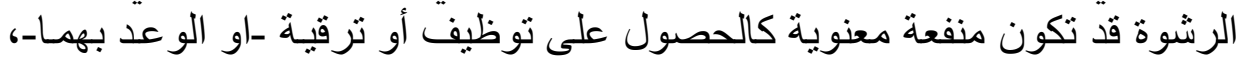

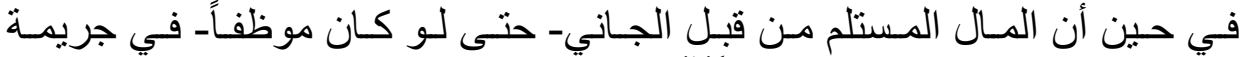
الإحتيال لا يمكن أن يكون إن الا مادياً (')

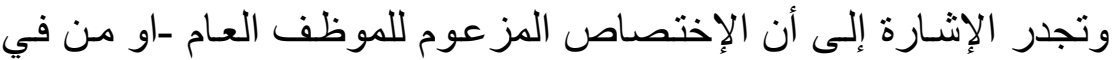

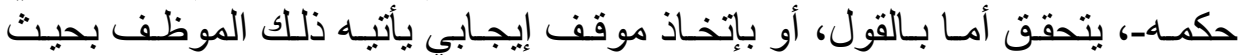

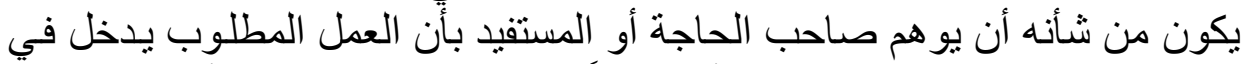

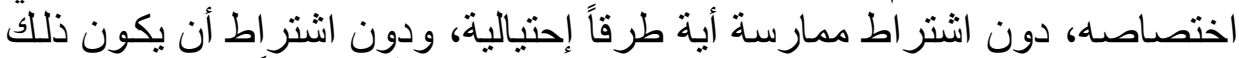

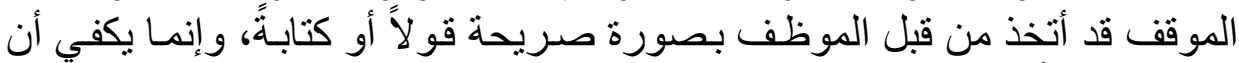

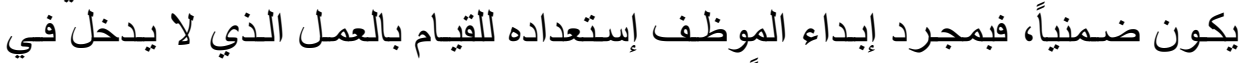

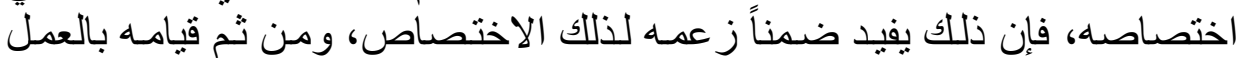

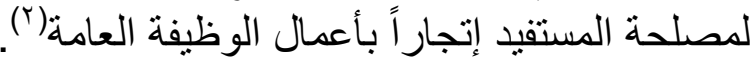

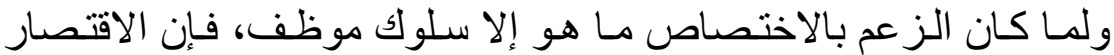

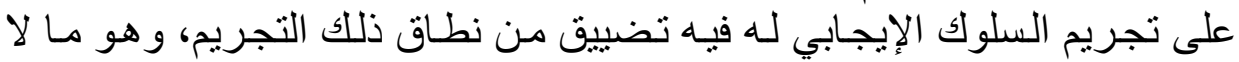

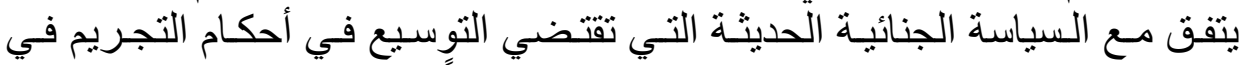

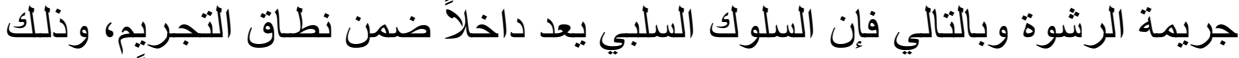

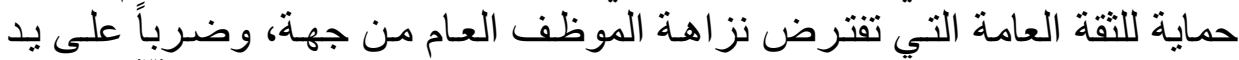

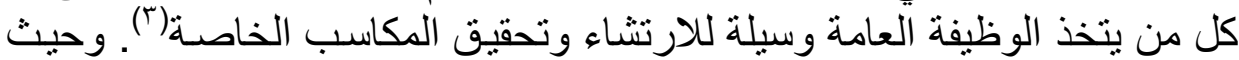

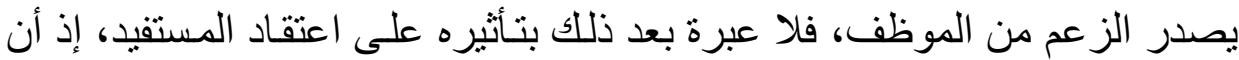

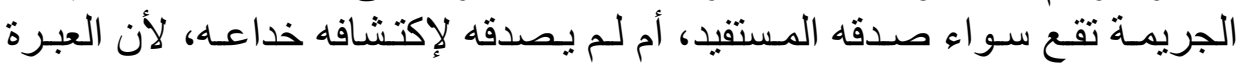

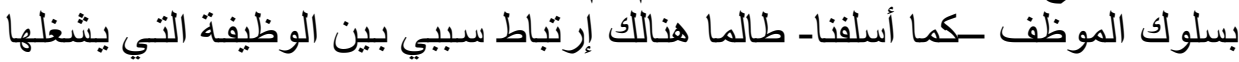

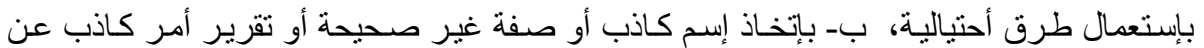

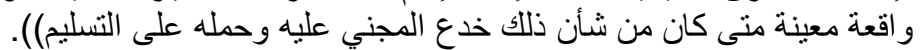

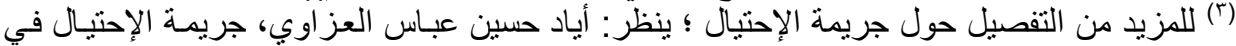

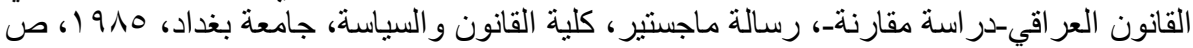

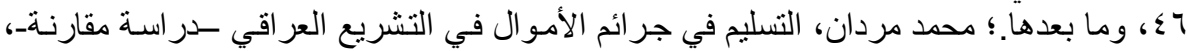

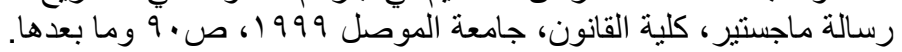

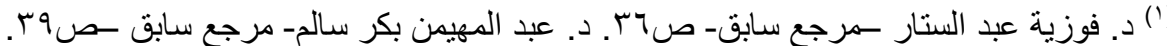

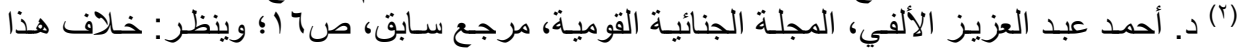

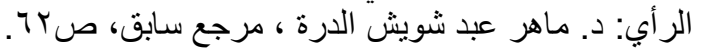




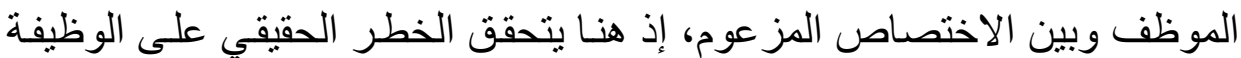

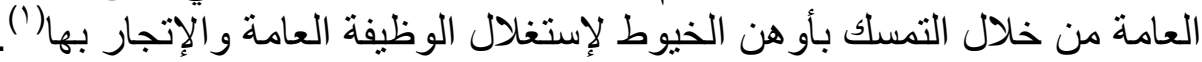

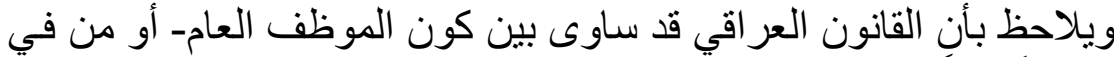

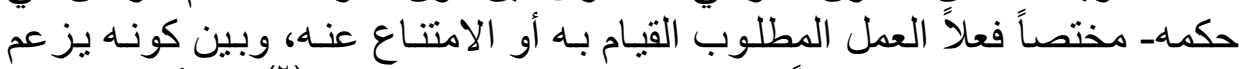

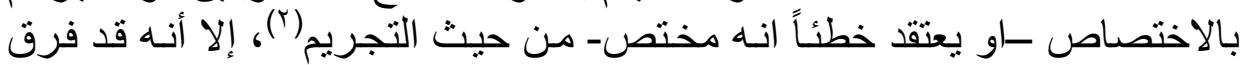

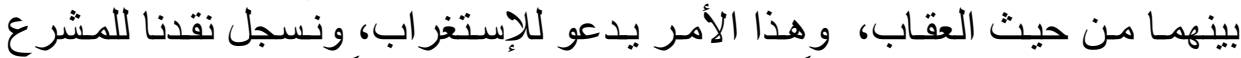

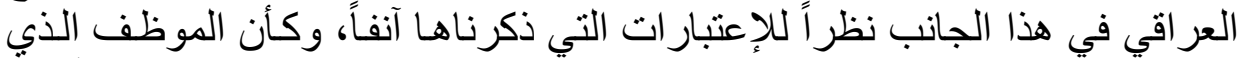

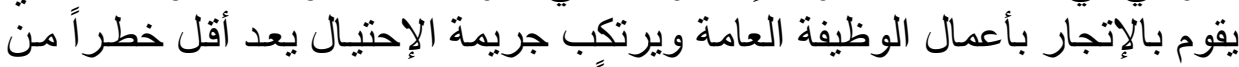

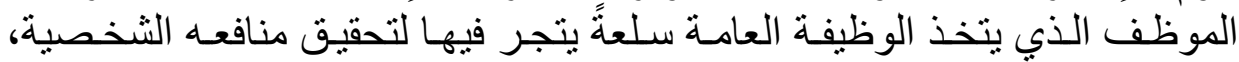

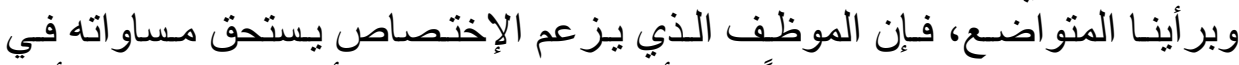

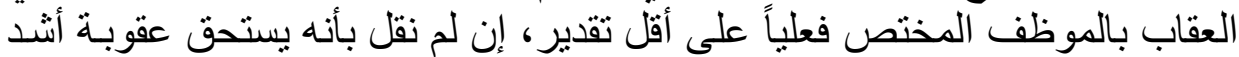

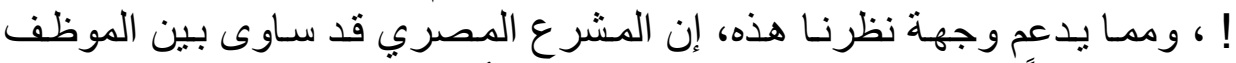

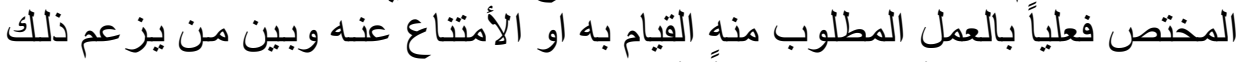

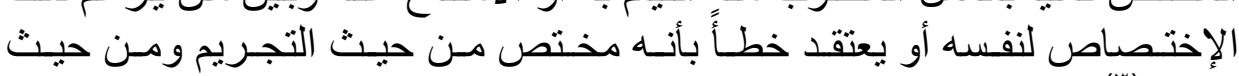

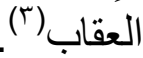

(r) د. محمود نجيب حسني، جر ائم الإعتداء على الأشخاص، مرجع سابق، ص آ؟؛ د. ماهر عبد شويش

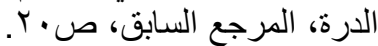

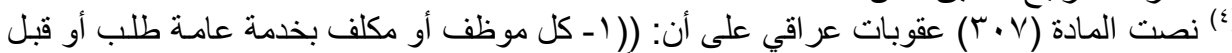

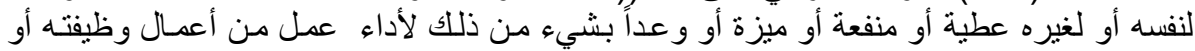

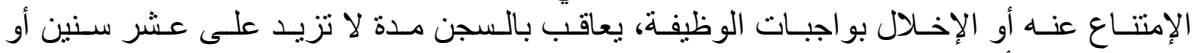

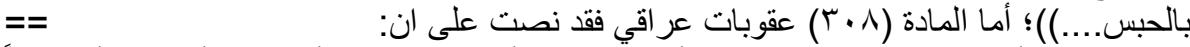

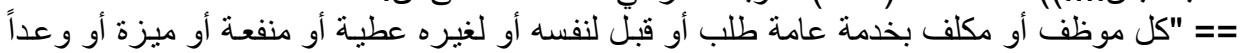

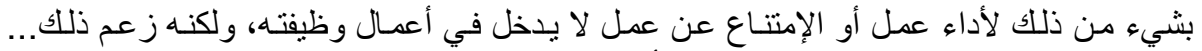

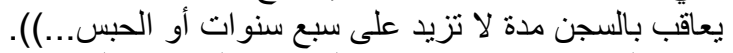

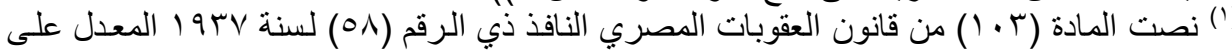

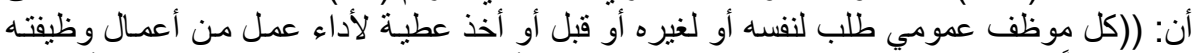

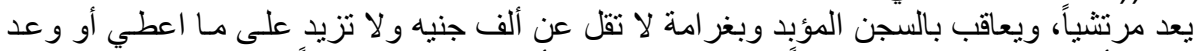

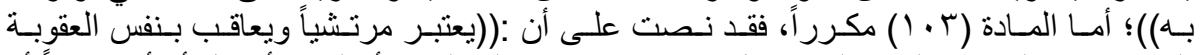

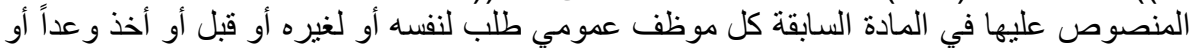

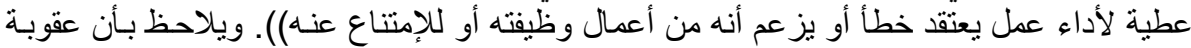

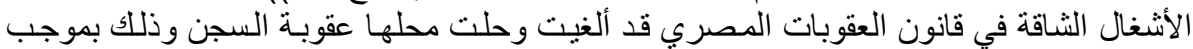

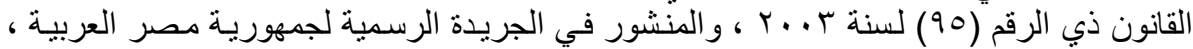

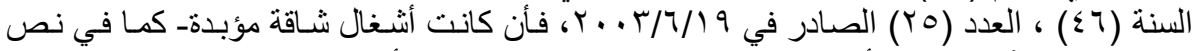

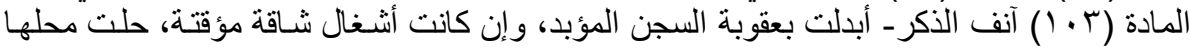
عقوبة السجن المؤقت. وللمزيد من التفصيل حول ذلك، ينظر : سـعد صـالح شكطي نجم الجبوري- 


\section{:}

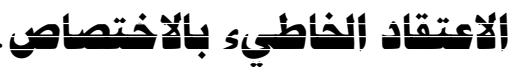

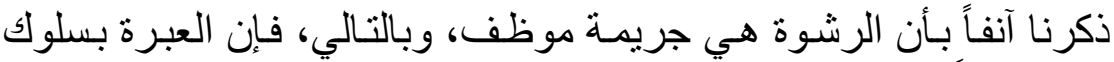

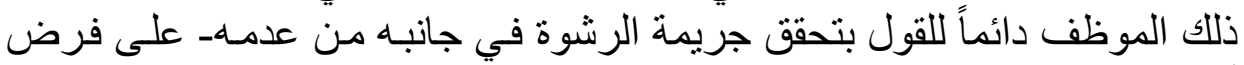

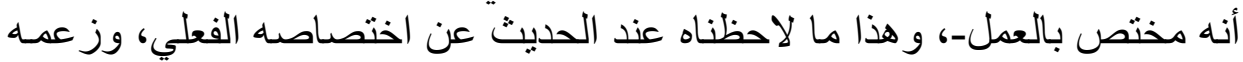

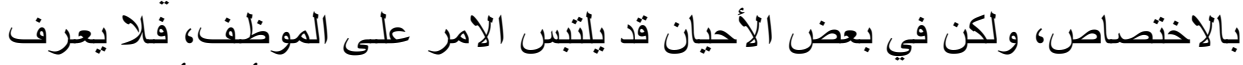

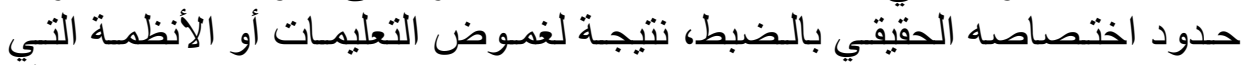

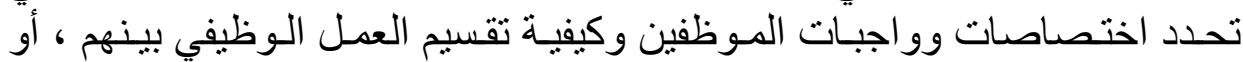

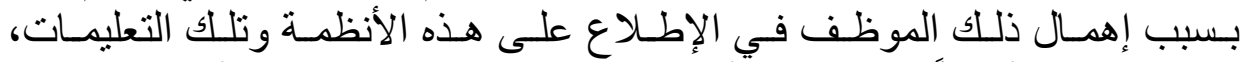

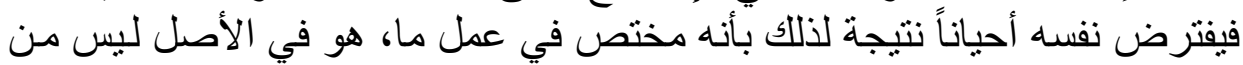

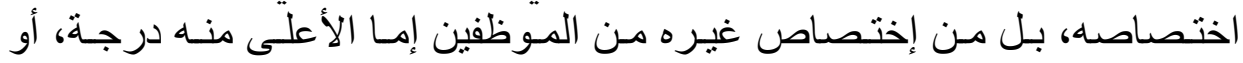

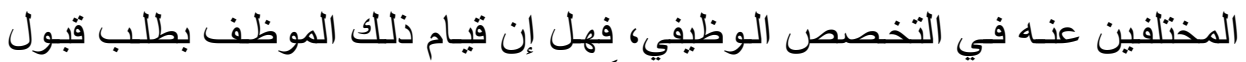

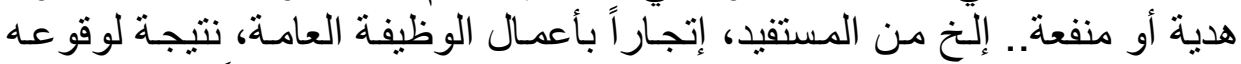

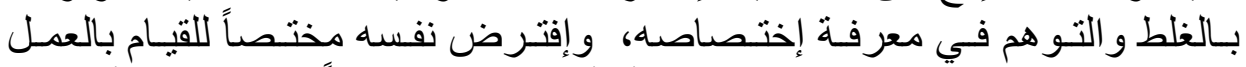

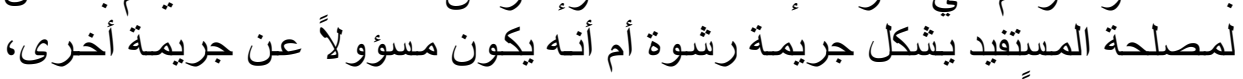
كالإحتيال مثلالٌ

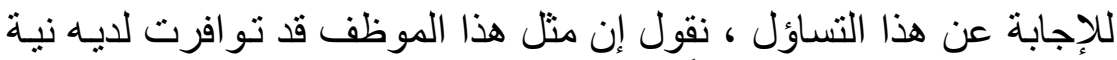

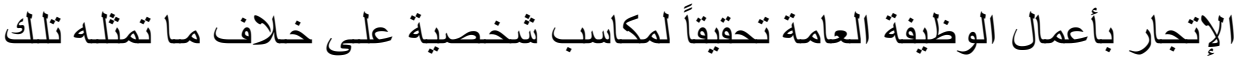

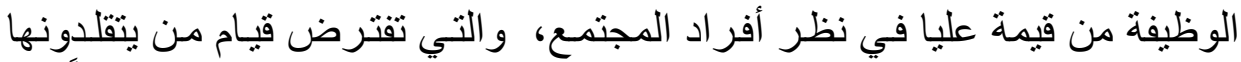

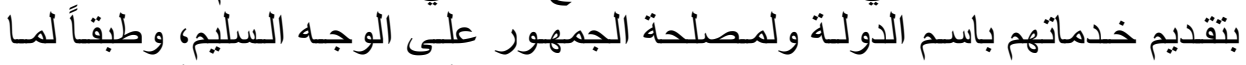

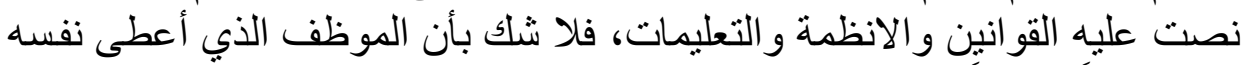

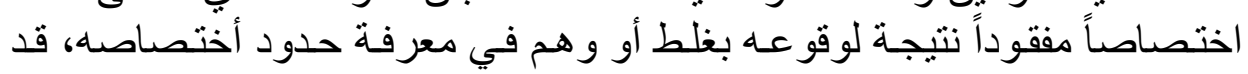

الجر ائم الإرهابية في القانون الجنائي- دراسة مقارنة في الأحكام الموضو عيةـ أطروحة دكتور اهـاه،

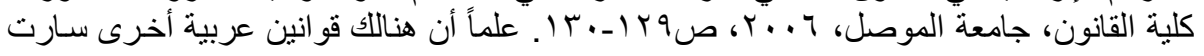

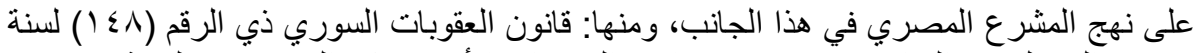

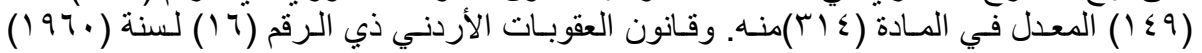

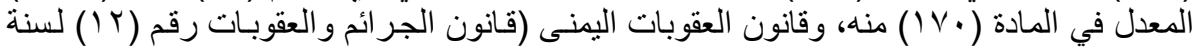

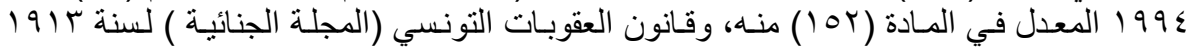

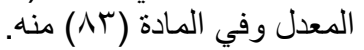




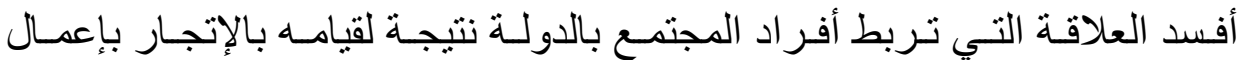

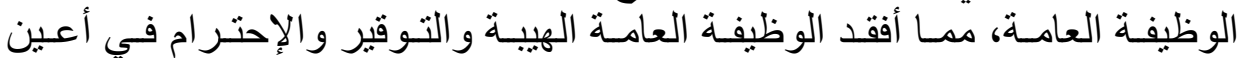

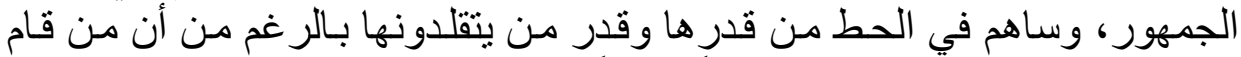

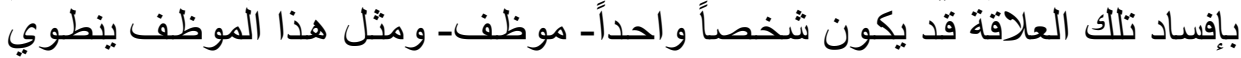

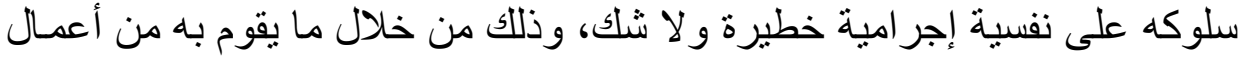

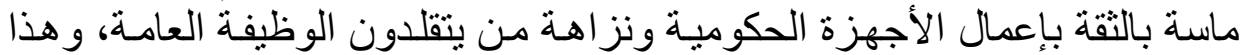

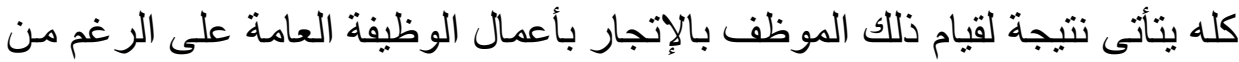

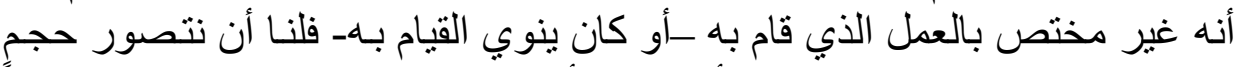

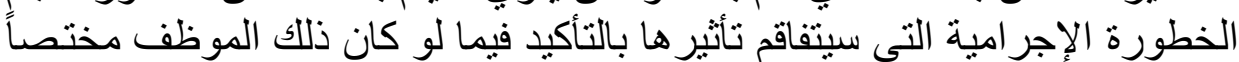

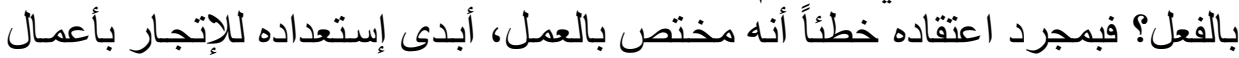

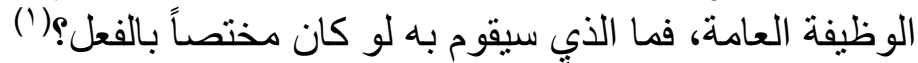

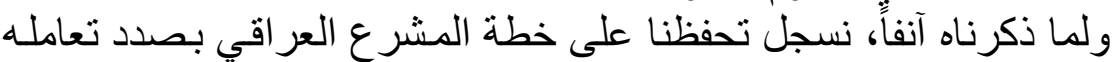

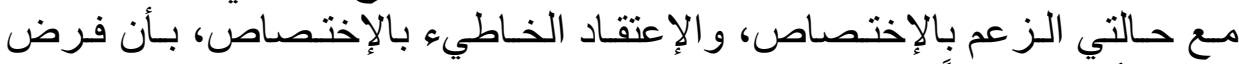

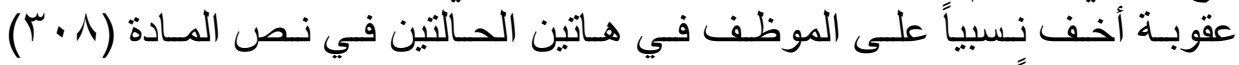

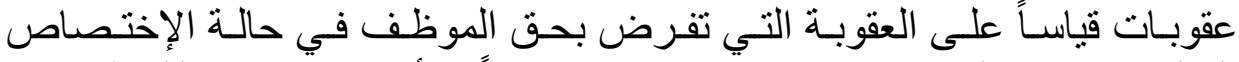

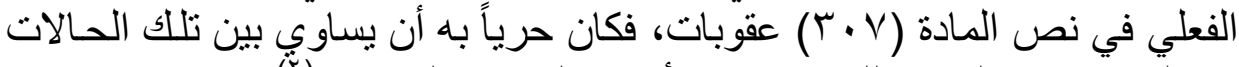

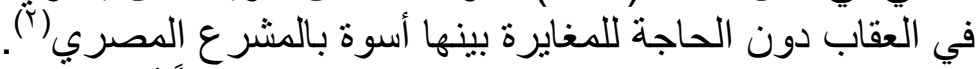

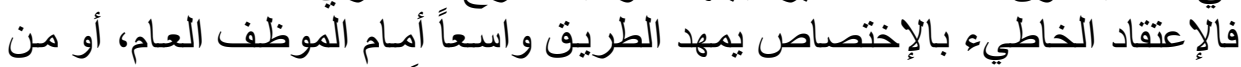

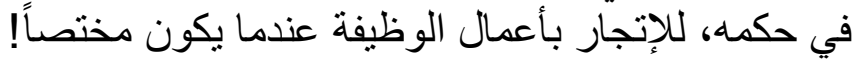

:

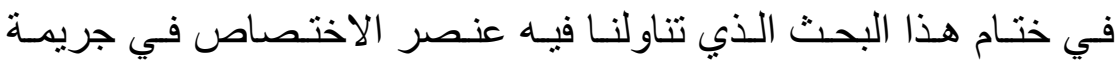

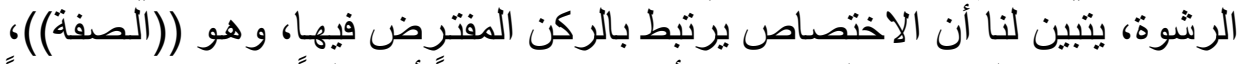
إذ يشترط في الجـاني ((المرتشي)) أن يكون موظفاً أو مكلفاً بخدمـة عامـة طبقاً

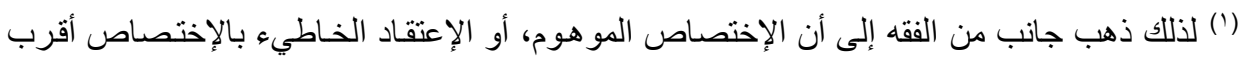

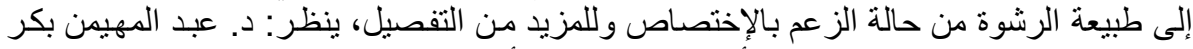

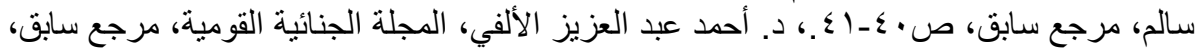

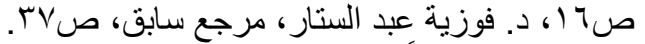

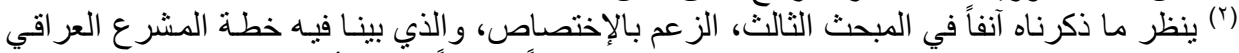

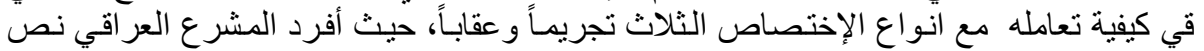

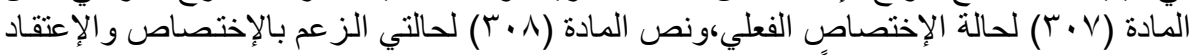
الخاطيء بالإختصاص. وتلافياً للتكر ار نحيل القارئ الكريم إلى هنآك. 


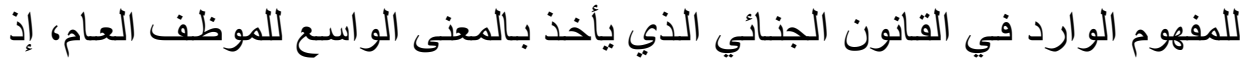

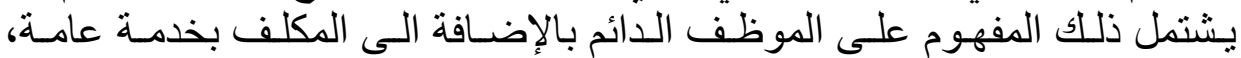

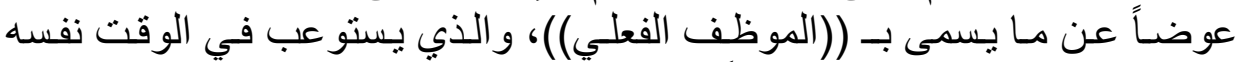

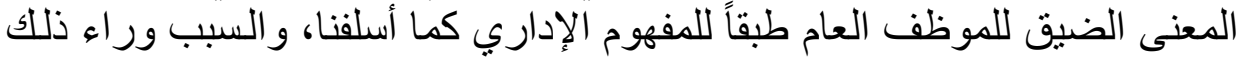

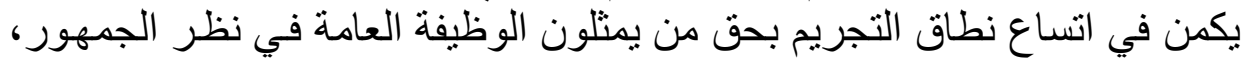

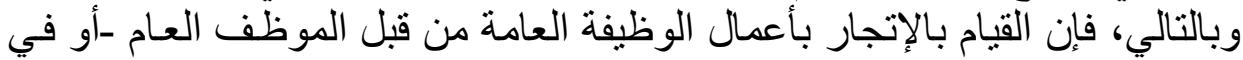

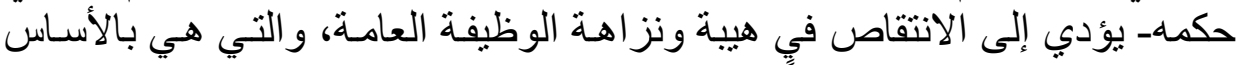

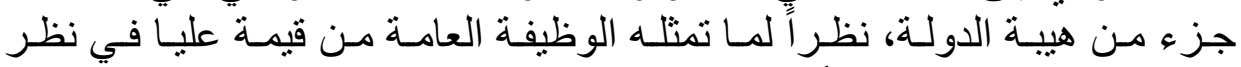

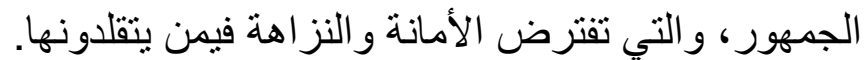

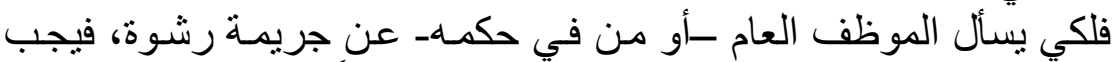

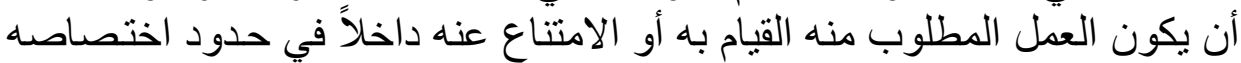

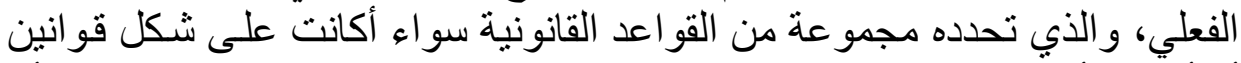

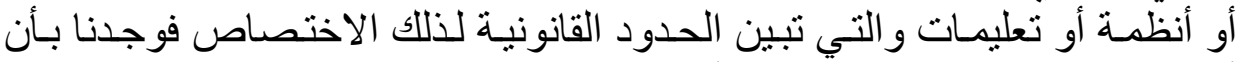

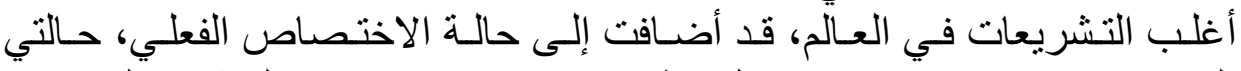

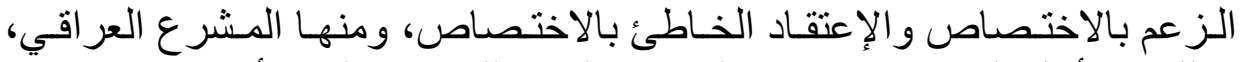

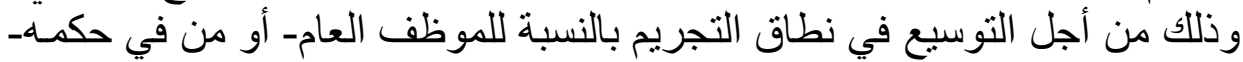

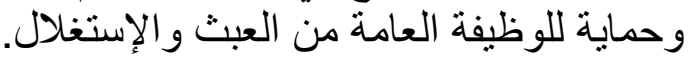

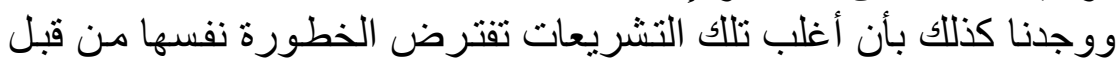

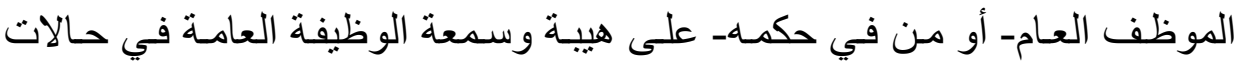

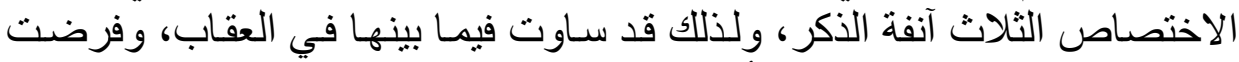

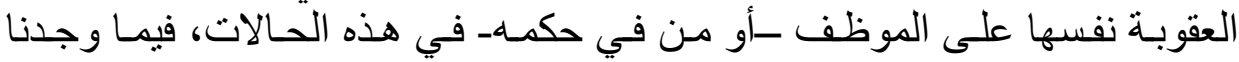

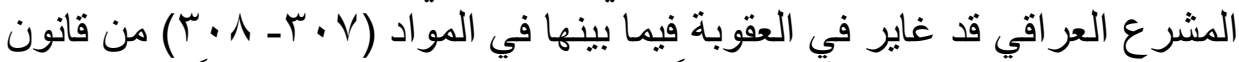

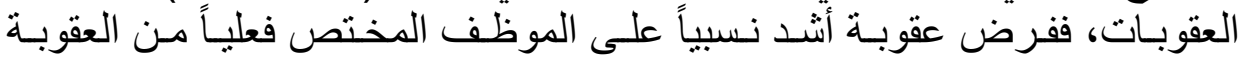

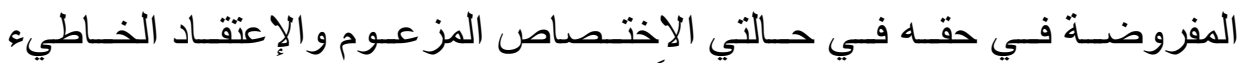

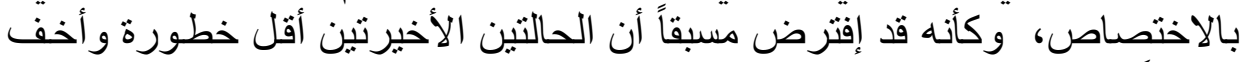

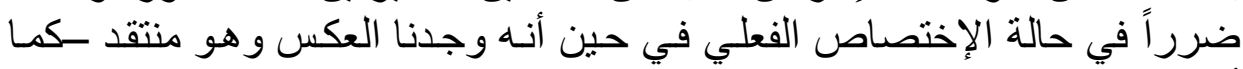

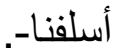

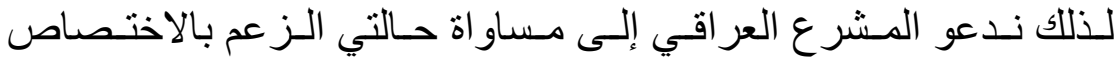

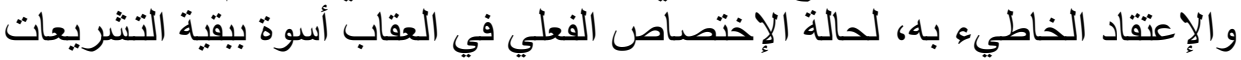




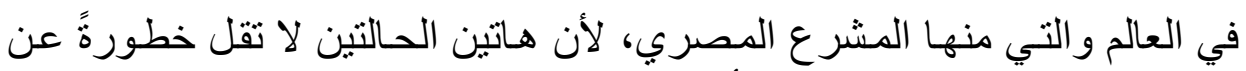

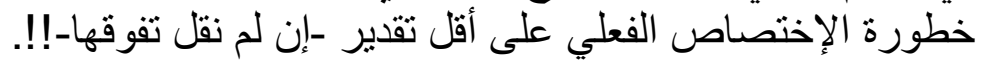

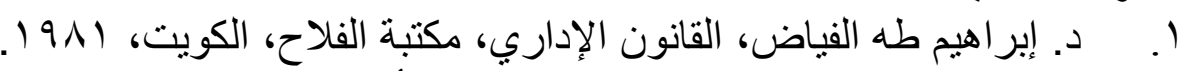

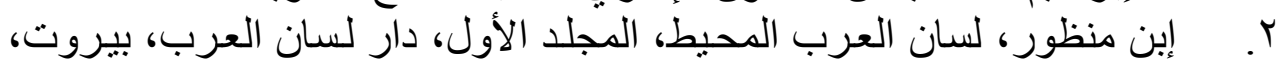

\section{بدون سنة طبع.}

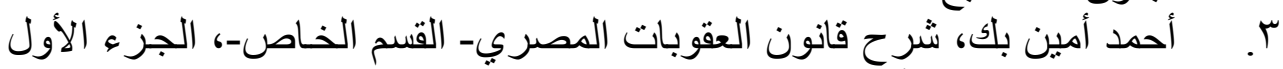

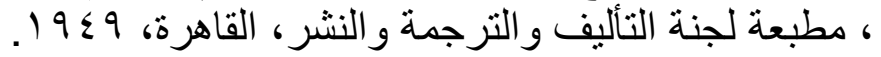

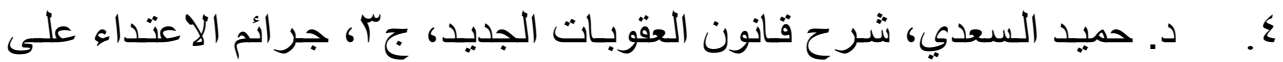

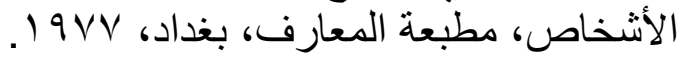

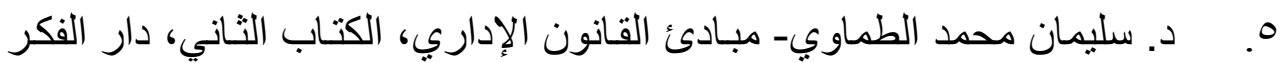

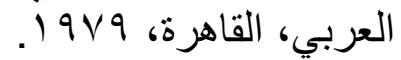

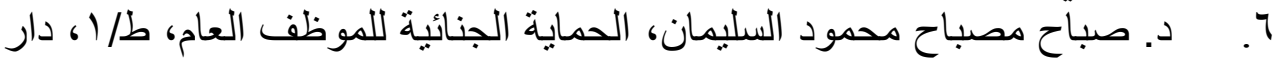

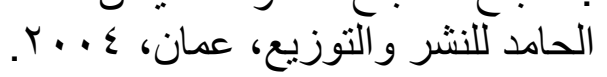

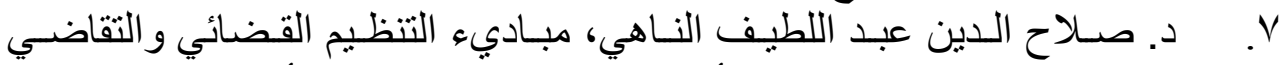

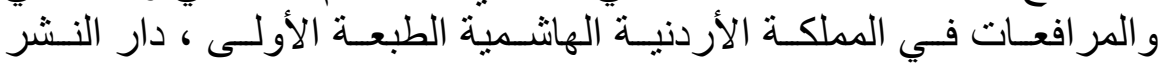

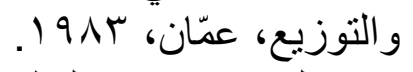

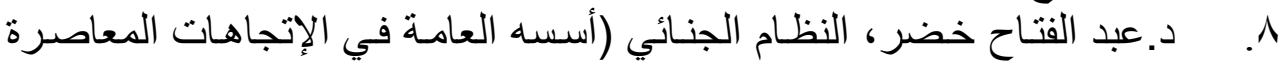

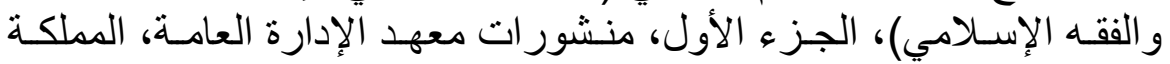

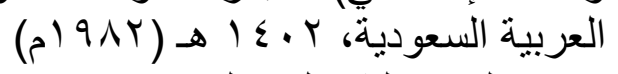

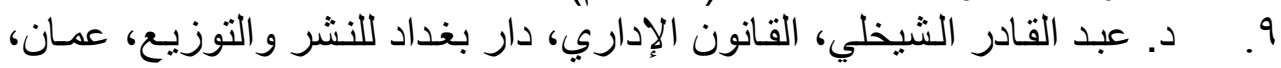

$$
.199 \leq
$$

• 1. علي بـن هاديـة وآخرون، القـاموس الجديد للطـلاب، الشركة الوطنبـة للنشر

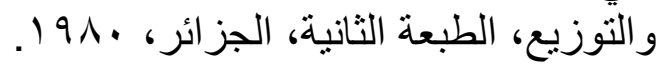

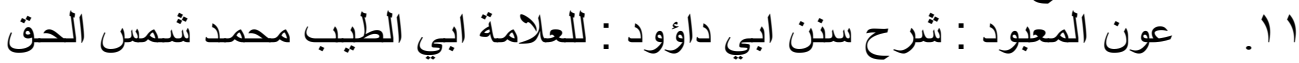

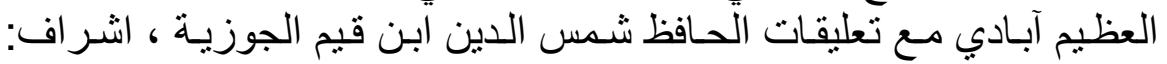

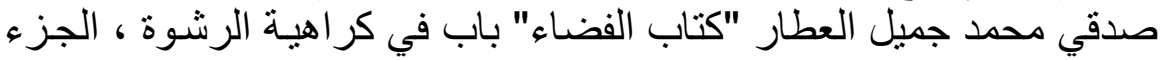

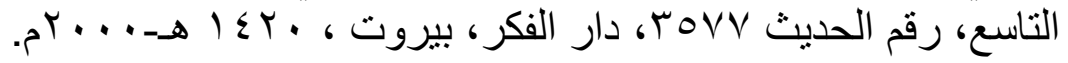

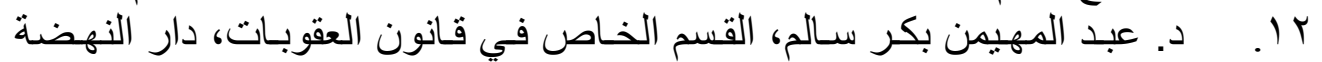

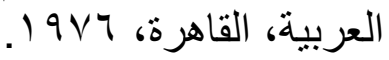


rا. . د. فخري عبد الرزاق صلبي الحديثي، شرح قانون العقوبات ـالقسم الخاص-

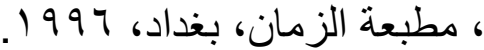

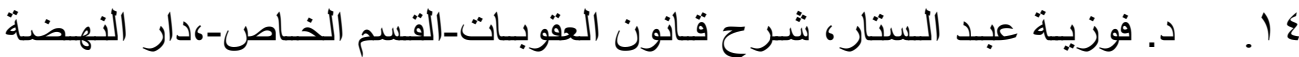

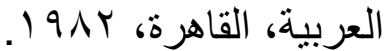

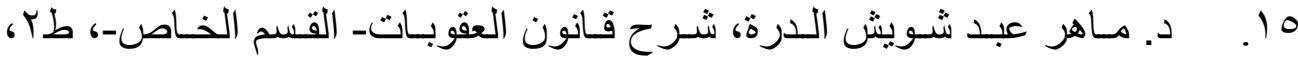

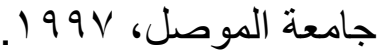

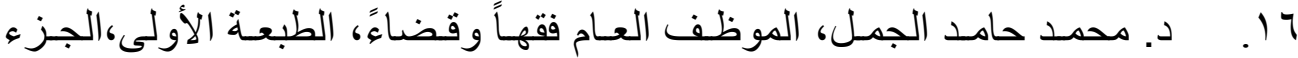

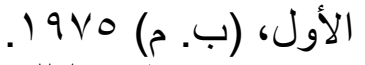

V ا. د. محمد مصطفى القللي، في المسؤولية الجنائية، مطبعة جامعة فؤاد الأول،

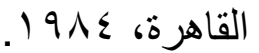

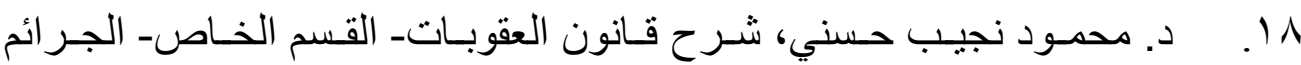

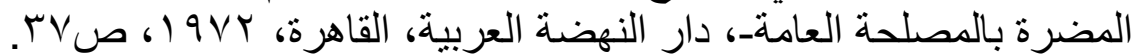
ثانياً: الرسائل والاطاريح الجامعية:

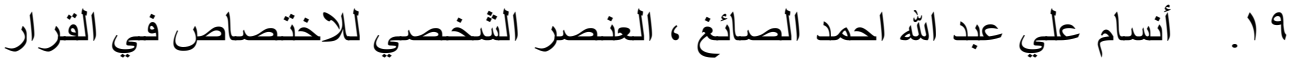

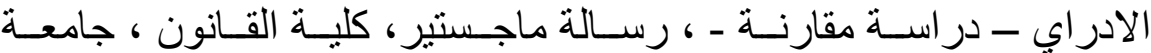

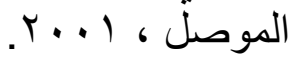

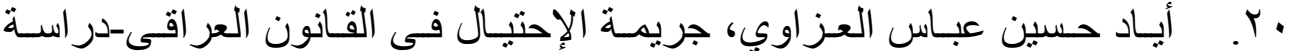

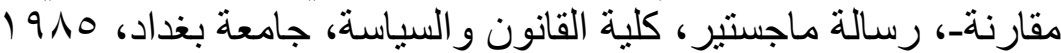

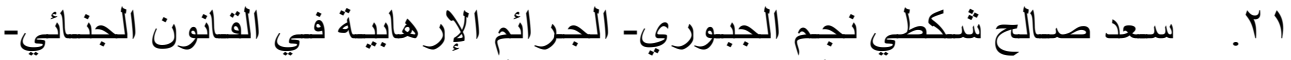

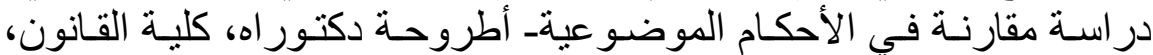

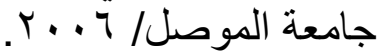

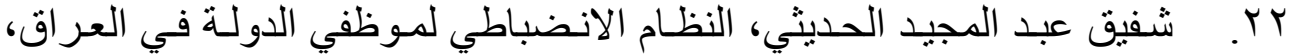

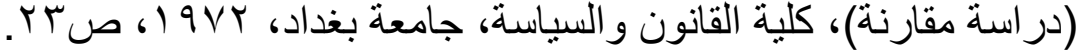

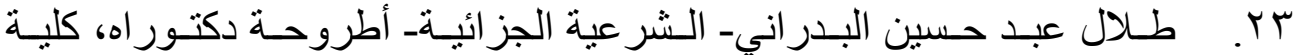

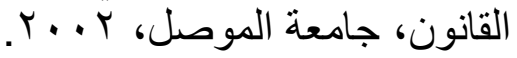

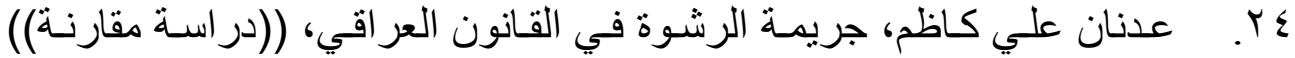

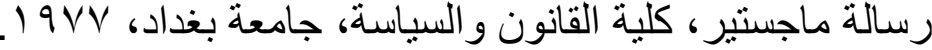

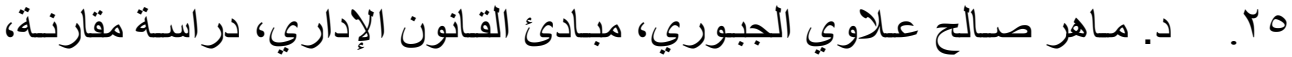

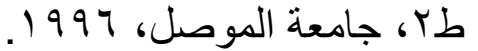

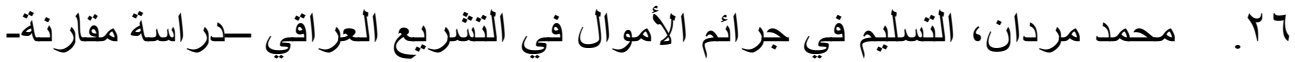

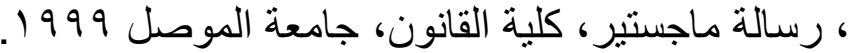


YV

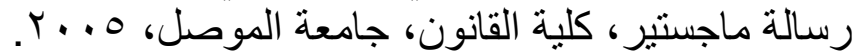

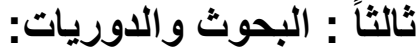

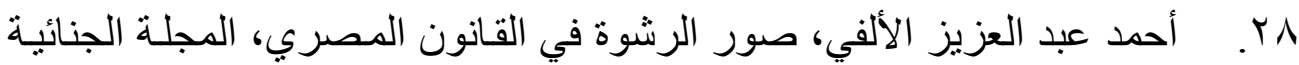

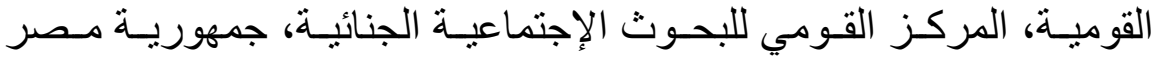

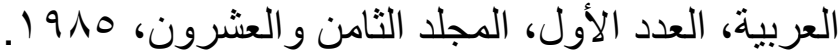

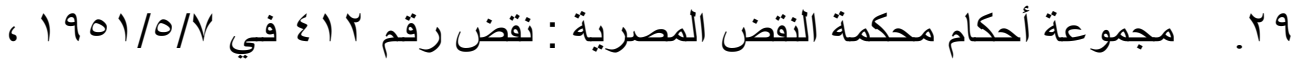

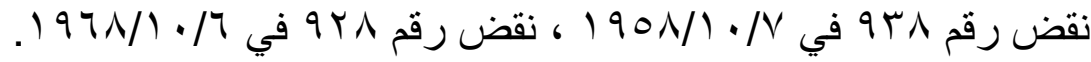

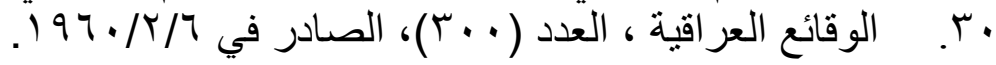

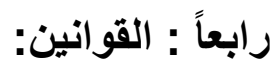

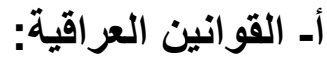

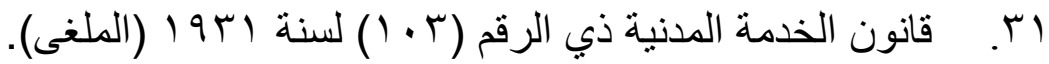

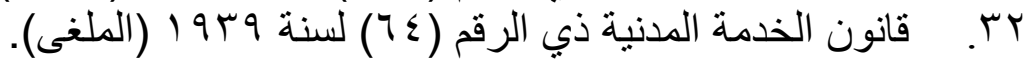

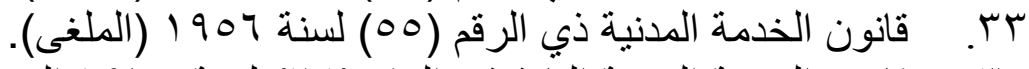

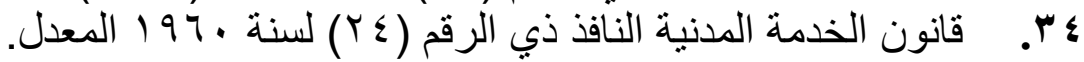

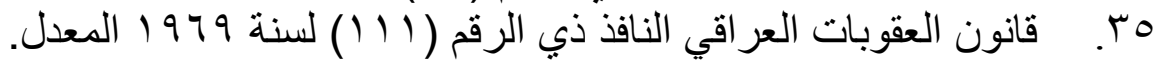

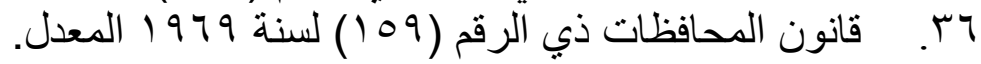

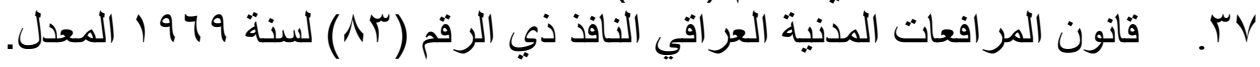

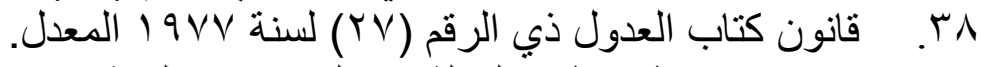

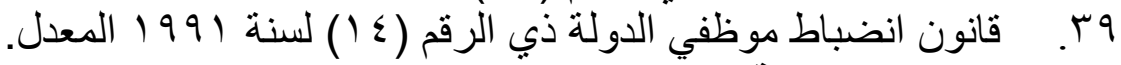

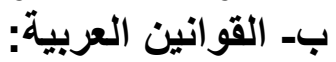

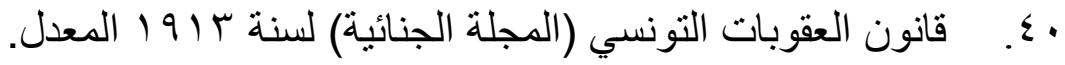

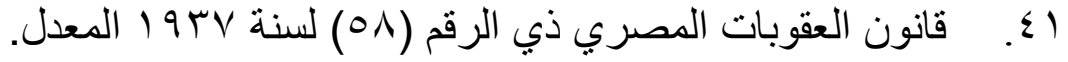

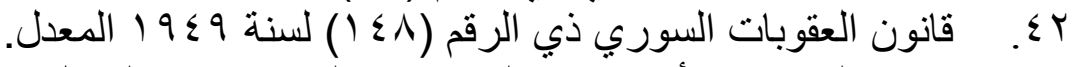

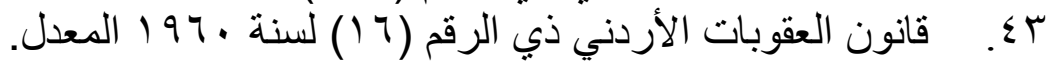

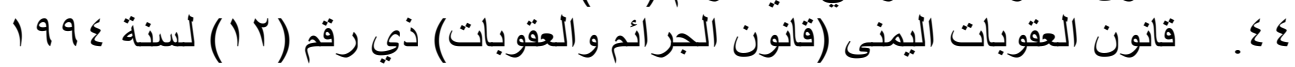

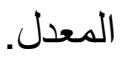

